\title{
Natural products inhibitors of the enzyme acetylcholinesterase
}

\author{
José M. Barbosa Filho ${ }^{*}$, Karina C. Paula Medeiros ${ }^{1}$, Margareth de Fátima F.M. Diniz, \\ Lê̂nia M. Batista ${ }^{1}$, Petrônio F. Athayde-Filho ${ }^{1}$, Marcelo S. Silva ${ }^{1}$,Emídio V.L. da-Cunha ${ }^{1}$, \\ Jackson R.G. Silva Almeida', Lucindo J. Quintans-Júnior ${ }^{2}$ \\ ${ }^{1}$ Laboratório de Tecnologia Farmacêutica "Delby Fernandes de Medeiros", Universidade Federal da Paraíba, \\ Caixa Postal 5009, 58051-970, João Pessoa, PB, Brazil, \\ ${ }^{2}$ Universidade Federal do Vale do São Francisco, Caixa Postal 252, \\ 56306-410, Petrolina, PE, Brazil
}

\begin{abstract}
RESUMO: "Produtos naturais inibidores da enzima acetilcolinesterase". A Doença de Alzheimer (DA) é uma patologia neurodegenerativa, progressiva, que afeta principalmente a população idosa, responsável por $50-60 \%$ dos casos de demência em pessoas com mais de 65 anos de idade. Os principais sintomas associado a DA envolve deficiência orgânica cognitiva, principalmente perda de memória. Outras características associadas com os estágios avançados de DA inclui déficit na linguagem, depressão, problemas de comportamento, inclusive agitação, alterações de humor e psicose.Um dos mais promissores caminhos para tratar esta doença é aumentar o nível de acetilcolina no cérebro usando inibidores da acetilcolinesterase (AChE). Este trabalho teve como objetivo revisar a literatura das plantas e substâncias encontradas nas plantas, inibidores da enzima acetilcolinesterase. Foram levantadas 309 plantas e 260 substâncias isoladas de plantas que foram classificados em grupos químicos adequados, os modelo testados, e suas atividades. Foram consultados 175 referências.
\end{abstract}

Unitermos: Inibidores da Acetilcolinesterase, AchE, doença de Alzheimer, distúrbios neurodegenetivos, plantas medicinais, produtos naturais, revisão.

\begin{abstract}
Alzheimer's disease (AD) is a progressive, neurodegenerative pathology that primarily affects the elderly population, and is estimated to account for $50-60 \%$ of dementia cases in persons over 65 years of age. The main symptoms associated with AD involve cognitive dysfunction, primarily memory loss. Other features associated with the later stages of AD include language deficits, depression, behavioural problems including agitation, mood disturbances and psychosis. One of the most promising approaches for treating this disease is to enhance the acetylcholine level in the brain using acetylcholinesterase (AChE) inhibitors. The present work reviews the literature on plants and plant-derived compounds inhibitors of enzyme acetylcholinesterase. The review refers to 309 plant extracts and 260 compounds isolated from plants, which are classified in appropriate chemical groups and model tested, and cites their activity. For this purpose 175 references were consulted.
\end{abstract}

Keywords: Acetylcholinesterase inhibitors, AChE, Alzheimer's disease, neurodegenerative disorders, medicinal plants, natural products, review.

\section{INTRODUCTION}

The enzyme acetylcholinesterase (AChE) catalyses the hydrolysis of the ester bound of acetylcholine (ACh) to terminate the impulse transmitted action of ACh through cholinergic synapses (Stryer, 1995). Although the basic reason of Alzheimer's disease (AD) is not clear so far, $\mathrm{AD}$ is firmly associated with impairment in cholinergic transmission. A number of AChE inhibitors have been considered as candidates for the symptomatic treatment of $\mathrm{AD}$ as the most useful relieving strategy (Howes et al., 2003).

Reversible inhibitors of cholinesterase are currently used in clinical trials examining the treatment of Alzheimer's disease. Anticholinesterase may interact with the central cholinergic system to improve memory and cognitive deficits of the patients by diminishing the breakdown of acetylcholine at the synaptic site in the brain. However, the therapeutic window is small, and testing of the inhibitory effect on acetylcholinesterase (AChE) in erythrocytes has been proposed as a guide to the efficacy and safety of putative therapies.

Alzheimer's disease is a progressive degenerative neurologic disorder resulting in impaired memory and behavior. Epidemiological data indicate a potentially considerable increase in the prevalence of the disease over the next two decades (Johnson et al., 2000). $\mathrm{AD}$ affects up to $5 \%$ of people over 65 years, rising to $20 \%$ of those over 80 years (Camps et al., 2000a). Most treatment strategies have been based on the cholinergic hypothesis which postulated that memory impairments in patients suffering from this disease result from a 
deficit of cholinergic function in brain. Cholinergic neurotransmission is specially affected in patients with Alzheimer's disease. One of the most promising approaches for treating this disease is to enhance the acetylcholine level in brain using acetylcholinesterase inhibitors (Enz et al., 1993). Several AChE inhibitors are being investigated for the treatment of Alzheimer's disease. However, only tacrine (1), donezepil (2), rivastigmine (3) and galanthamine (4) have been approved by the Food and Drug Administration in the United States (Zarotsky et al., 2003). Among the other strategies under investigation, monoamine oxidase $\mathrm{B}$ (MAO-B) inhibitors have also been proposed for the treatment of AD. Recent studies have shown that MAO-B activity can increase up to 3-fold in the temporal, parietal and frontal cortex of AD patients compared with controls. This increase in MAO-B activity produces an elevation of brain levels of hydroxyl radicals, which has been correlated with the development of $A \beta$ plaques. $A \beta$ is the main component of the senile plaques found in $\mathrm{AD}$ brains and any compound able to inhibit its aggregation might be regarded as potentially useful in the treatment of the disease (Bruhlmann et al., 2001).

Nature is a rich source of biological and chemical diversity. The unique and complex structures of natural products cannot be obtained easily by chemical synthesis. A number of plants in the world have been used in traditional medicine remedies. Huperzine A (5) is a natural compound first isolated from Chinese medicine
Huperzia serrata (Thumb.) in 1986, is a potent, reversible and selective inhibitor of AChE.

In a previous paper this research group has reviewed crude plant extracts and chemically defined molecules with potential antitumor activity for mammary (Moura et al., 2001), cervical (Moura et al., 2002) and ovarian neoplasias (Silva et al ., 2003), as inhibitors of HMG CoA reductase (Gonçalves et al., 2000), central analgesic activity (Almeida et al., 2001), employed in prevention of osteoporosis (Pereira et al., 2002), for the treatment of Parkinson's disease (Morais, 2003), with antileishmanial (Rocha et al., 2005), hypoglycaemic (Barbosa-Filho et al., 2005) and antiinflammatory activity (Falcão et al., 2005, Barbosa-Filho et al., 2006). The present work reviews the literature on plants and plant-derived compounds inhibitors of enzyme acetylcholinesterase.

\section{MATERIALS AND METHODS}

The keywords used for this review were medicinalplants, naturalproducts, andacetylcholinesterase inhibitors. The search perfound using Chemical Abstracts, Biological Abstracts and the data bank of the University of Illinois at Chicago, NAPRALERT (Acronym for NAtural PRoducts ALERT), updated to December 2004 The references obtained were later consulted.<smiles>Nc1c2c(nc3ccccc13)CCCC2</smiles>

(1)<smiles>COc1ccc2c3c1OC1C[C@H](O)C=CC31CCN(C)C2</smiles>

(4)<smiles>CCN(C)C(=O)Oc1cccc(C(C)N(C)C)c1</smiles>

(2)

(3)<smiles>CC=C1C2=CCC(=O)NC2=C1C1(N)C=C(C)CC1</smiles><smiles>CNC(=O)Oc1ccc2c(c1)C1(C)CCN(C)[C@H]1N2C</smiles>

(5)

Figure 1. Representative examples of synthetic (1-3) and natural (4-6) products inhibitors of the enzyme acetylcholinesterase 


\section{RESULTS AND DISCUSSION}

Consultation of various types of literature sources resulted in elaboration of a list of natural products (Table 1 and 2) evaluated specifically for acetylcholinesterase inhibition. It should be noted that most of references cited are not first-hand observations, but secondary sources. For details on the models or mechanism-based bioassays utilized for selecting plant extracts and pure compounds against acetylcholinesterase, the original references should be consulted.

\section{Plant extracts inhibitors of acetylcholinesterase enzyme}

Acetylcholine is a neurotransmitter inhibited primarily by acetylcholinesterase (AChE) and secondly by butyrylcholinesterase (BChE), considered to play a role in the pathology of AD (Hebert et al., 1995). Despite the unknown etiology of $\mathrm{AD}$, elevation of acetylcholine amount through AChE enzyme inhibition has been accepted as the most effective treatment strategy against AD. Therefore, AChE inhibitors have become the remarkable alternatives in treatment of $\mathrm{AD}$. However, the present drugs (tacrine, rivastigmine and donezepil) with AChE inhibitory activity possess some side effects (Schneider, 2001). Consequently, it is compulsory to develop new drugs in order to combat AD (Viegas-Junior et al., 2004).

The history of drug discovery showed that plants are highly rich sources in the search for new active compounds and they have become a challenge to modern pharmaceutical industry. Many synthetic drugs owe their origin to plant-based complementary medicine. Since $\mathrm{AD}$, one of the most common cause of death worldwide, has become a threaten to public health, new treatment strategies based on medicinal plants have been focused (Howes et al., 2003; Orhan et al., 2004).

A recent study with Brazilian plants showed excellent results for the species Amburana cearensis, Lippia sidoides, Paullinia cupana, Plathymiscium floribundum and Solanum asperum (Trevisan; Macedo, 2003). Since the plants have been used in treatment of memory disfunction in some folk medicines since centuries the present study presents a review of 309 plants belong to 92 botanical families tested against acetylcholinesterase inhibition. The plants are listed in Table 1, in alphabetical order of their family, scientific name, country, plant part used, type of extract, dose/ concentration, result and references.

\section{Chemically-defined molecule as inhibitors of acetylcholinesterase enzyme}

The prototype for the centrally acting AChE inhibitors was tacrine, the first drug to be approved in the United States $\left(\right.$ Cognex $\left.{ }^{\circledR}\right)$ for the treatment of $A D$.
However, its severe side effects such hepatotoxicity and gastrointestinal upset, represent an important drawback (Camps et al., 2000). The results of the studies on tacrine spurred the development of other centrally acting reversible $\mathrm{AChE}$ inhibitors, such as the recently marketed galanthamine $\left(\right.$ Nivalin $\left.^{\circledR}\right)$, donezepil (Aricept ${ }^{\mathbb{R}}$ ) and rivastigmine $\left(\right.$ Exelon $\left.^{\circledR}\right)$ or the natural product (-)huperzine $\mathrm{A}$, which is currently undergoing extensive clinical trials, showing considerable promise for the palliative treatment of $\mathrm{AD}$.

Galanthamine, a long acting, selective, reversible and competitive AChE inhibitor, is considered to be more effective in the treatment of $A D$ and to have fewer limitations (Rhee et al., 2001). Recently it has reported wich because of bioavailability problems and possible side-effects, there still is great interest in finding better AChE inhibitors.

Donezepil was developed in order to overcome the disadvantages of physostigmine and tacrine, and later approved by the FDA for treatment of AD. It is highly selective for acetylcholinesterase with a significantly lower affinity for butyrylcholinesterase (Racchi et al., 2004).

Rivastigmine is a carbamilating, pseudoirreversible acetylcholinesterase inhibitor which in preclinical biochemical studies has shown a significant nervous system selectivity (Racchi et al., 2004).

(-)-Huperzine A is a natural compound first isolated from Chinese medicine Huperzia serrata (Thumb.) in 1986. It is a potent, reversible and selective inhibitor of $\mathrm{AChE}$ with a rapid absorption and penetration into the brain in animal tests. Compared to tacrine, physostigmine (6), galanthamine and donezepil, huperzine A possesses a longer duration of action and higher therapeutic index, and the peripheral cholinergic side effects are minimal at therapeutic doses (Camps et al., 2000; Li et al., 2004). Huperzine A possesses higher selectivity and has almost no effect on butyrylcholinesterase. In China, huperzine A has already been approved as a palliative drug for AD (Högenauer et al., 2001).

We founded 260 chemically defined natural molecules reported in the literature, which have been evaluated for acetylcholinesterase inhibition. The compounds tested, which have been isolated and identified belong to the classes of alkaloids (139), monoterpenes (27), coumarins (18), triterpenes (17), flavonoids (14), benzenoids (13), diterpenes (8), oxygen heterocycles (5), sesquiterpenes (5), stilbenes (3), lignans (2), sulfur compounds (2), proteids (2), polycyclic (1), quinoid (1), benzoxazinone (1), carotenoid (1) and alycyclic (1).

\section{CONCLUSION}

The present work shows that most of the plant extracts tested showed inhibitory activity against acetylcholinesterase and they could be considered for 
further studies in the treatment of AD. In particular, the species belonging to Amaryllidaceae, Apiaceae, Asteraceae, Fabaceae and Fumariaceae were the most studied. Since most of acetylcholinesterase inhibitors are known to contain nitrogen, the higher activity of these extracts may be due to their rich alkaloidal content. The alkaloids are the major compounds isolated from this species and shows inhibitory activity for the acetylcholinesterase. More research is needed to further explore the actions of this alkaloids in the search of promising treatment for $\mathrm{AD}$.

\section{ACKNOWLEDGEMENTS}

The authors wish to express their sincere thanks to the College of Pharmacy, The University of Illinois at Chicago, Chicago, Illinois 60612-7231, U.S.A., for helping with the computer-aided NAPRALERT search and $\mathrm{CNPq} / \mathrm{CAPES} /$ Brazil for financial support.

\section{REFERENCES}

Ahmad I, Anis I, Malik A, Nawaz SA, Choudhary MI 2003. Cholinesterase inhibitory constituents from Onosma hispida. Chem Pharm Bull 51: 412-414.

Akiyama T, Ichikawa W, Matsui Y, Haruyama H 1991. Stilbene trimer compound as acetylcholinesterase inhibition. Paten Japan Kokai Tokkyo Koho-03 294,273: 4pp.

Almeida RN, Navarro DS, Barbosa-Filho JM 2001. Plants with central analgesic activity Phytomedicine 8: 310-322.

Alozie SO, Sharma RP, Salunkhe DK 1979. Inhibition of rat cholinesterase isoenzymes in vitro and in vivo by the potato alkaloid, $\alpha$-chaconine. J Food Biochem 2: 259276.

Anon 1991. Huperzine A. Drugs of the future 16: 577.

Anon 1992a. Huperzine A. Drugs of the future 17: 518-519.

Anon 1992b. Huperzine A. Drugs of the future 19: 595-596.

Antonious AG, Saito T, Miyata T 1983. Mode of action of antiffeding compounds in the larvae of the tobacco cutworm, Spodoptera litura (F.) (Lepodptera: Noctuidae). V. Inhibition of enzyme from the tobacco cutworm by chlodimeform and clerodin. Nippon Noyaku Gakkaishi 8: 591-593.

Asano N, Kato A, Yokoyama Y, Miyauchi M, Yamamoto M, Kizu H, Matsui K 1996. Calystegin N1, a novel nortropane alkaloid with a bridgehead amino group from Hyosciamus niger. Structure determination and glycosidase inhibitory activities. Carbohydr Res 284: 169-178.

Ashack RJ, McArty LP, Malek RS, Goodman FR, Peet NP 1980. Evaluation of rotenone and related compounds as antagonists of slow-reacting substance of anaphylaxis. J Med Chem 23: 1022-1026.

Astrakhan NB, Archer BG, Hilbelink DR 1980. Evaluation of subacute toxicity and teratogenicity of anatoxin A. Toxicon 18: 684-688.

Barbosa-Filho JM, Vasconcelos THC, Alencar AA, Batista LM, Oliveira RAG, Guedes DN, Falcão HS, Moura MD, Diniz MFFM, Modesto-Filho J 2005. Plants and their active constituents from South, Central, and North America with hypoglycemic activity. Rev Bras
Farmacogn 15: 392-413.

Barbosa-Filho JM, Piuvezam MR, Moura MD, Silva MS, Lima KVB, Cunha EVL, Fechine IM, Takemura OS 2006. Anti-inflammatory activity of alkaloids: A twentycentury review. Rev Bras Farmacogn 16: 109-139.

Benishin CG, Lee R, Wang LCH, Liu HJ 1991. Effects of ginsenoside RB-1 on central cholinergic metabolism. Pharmacology 42: 223-229.

Breuer H, Rangel M, Medina E 1982. Pharmacological properties of melochinine, an alkaloid producing Central American cattle paralysis. Toxicology 25: 223242.

Brossi A, Schonenberger B, Clark OE, Ray R 1986. Inhibition of acetylcholinesterase from electric EEL by (-)- and $(+)$-physostigmine and related compounds. FEBS Lett 201: 190-192.

Bruhlmann C, Ooms F, Carrupt PA, Testa B, Catto M, Leonetti F, Altomare C, Carotti A 2001. Coumarin derivatives as dual inhibithors of acetylcholinesterase and monoamine oxidase. J Med Chem 44: 3195-3198.

Camps P, El-Achab R, Morral J, Torrero DM, Badia A, Banos JE, Vivas NM, Barril X, Orozco M, Luque FJ 2000a. New tacrine-huperzine A hybrids (huprines): highly potent tight-binding acetylcholinesterase inhibitors of interest for the treatment of Alzheimer's disease. $J$ Med Chem 43: 4657-4666.

Camps P, Contreras J, El-Achab R, Morrla J, Torrero DM, Font-Bardia M, Solans X, Badia A, Vivas NM 2000b. New synthesis of rac-huperzine A and its Rac-7ethyl-derivative. Evaluation of several huperzine A analogues as acetylcholinesterase inhibitors. Tetrahedron 56: 4541-4553.

Calderon JS, Cespedes CL, Rosas R, Garibay FG, Salazar JR, Lina L, Aranda E, Kubo I 2001. Acetylcholinesterase and insect growth inhibitory activities of Gutierrezia microcephala on fall armyworm Spodoptera frugiperda J.E. Smith. Z Naturforsch Ser C 50: 382394.

Cardoso CL, Castro-Gamboa I, Silva DHS, Furlan M, Epifanio RA, Pinto AC, Rezende CM, Lima JÁ, Bolzani VS 2004. Indole glucoalkaloids from Chimarrhis turbinata and their evaluation as antioxidant agents and acetylcholinesterase inhibitors. J Nat Prod 67: 1882-1885.

Cheng DH, Tang XC 1998. Comparative studies of huperzine A, E2020 and tacrine on behavior and cholinesterase activities. Pharmacol Biochem Be 60: 377-386.

Choudhary MI, Khalid A, Sultani SZ, Rahman AU 2002. A new coumarin from Murraya paniculata. Planta Med 68: $81-83$

Choudhary MI, Shannaz S, Parveen S, Khalid A, Ayatollahi SAM, Rahman AU 2003. New triterpenoi alkaloid cholinesterase inhibitors from Buxus hyrcana. $J$ Nat Prod 66: 739-742.

Chun YT, Yip TT, Lau KL, Kong YC, Sankawa U 1979. A biochemical study on the hipotensive effect of berberine in rats. Gen Pharmacol 10: 177-182.

Chung YK, Heo HJ, Kim EK, Kim HK, Huh TL, Lim Y, Kim SK, Shin DH 2001. Inhibitory effect of ursolic acid purified from Origanum majorana L. on the acetylcholinesterase. Mol Cells 11: 137-143.

Cuevas L, Niemeyer HM 1993. Effect of hydroxamic acids from cereals on aphid cholinesterases. Phytochemistry 
34: 983-985.

De la Cruz JP, Quintero L, Villalobos MA, De la Cuesta FS 2000. Lipid peroxidation and glutathione system in hyperlipidemic rabbits: influence of olive oil administration. Biochem Bioph Acta 1485: 36-44.

Dhar SK, Johri RK, Zutshi U, Atal CK 1986. Effect of potassium embelate, a novel analgesic compound on the neurotransmitter content of cerebrospinal fluid of the dog. Curr Sci 55: 511-512.

El-Hassan A, El-Sayed M, Hamed AI, Rhee IK, Ahmed AA, Zeller KP, Verpoorte R 2003. Bioactive constituents of Leptadenia arborea. Fitoterapia 74: 184-187.

Enz A, Amstutz R, Boddeke H, Gmelin G, Malonowski J 1993. Brain selective inhibition of acetylcholinesterase: a novel approach to therapy for Alzheimer's disease. Prog Brain Res 98: 431-445.

Falcão HS, Lima IO, Santos VL, Dantas HF, Diniz MFFM, Barbosa-Filho JM, Batista LM 2005. Review of the plants with anti-infl ammatory activity studied in Brazil. Rev Bras Farmacogn 15: 381-391.

Ferguson PW, Medon PS, Briley TC, Watson CF 1983. Effects of Siberian ginseng extract on parathion toxicity in mice. Toxicologist 3: 51 .

Gattu M, Boss KL, Terry-Jr AV, Buccafusco JJ 1997. Reversal of scopolamine-induced deficits in navigational memory performance by the seed oil of Celastrus paniculatus. Pharmacol Biochem Be: 793-799.

Gonçalves MCR, Moura LSA, Rabelo LA, Barbosa-Filho JM, Cruz HMM, Cruz J 2000. Produtos naturais inibidores da enzima HMG CoA redutase. Rev Bras Farm 81: 63-71.

Gracza L 1985. Molecular pharmacological investigation of medicinal plant substances II. Inhibition of acetylcolinesterase by monoterpene derivatives in vitro. Z Naturforsch Ser C 40: 151-153.

Greenblatt HM, Kryger G, Lewis T, Silman I, Sussman JL 1999. Structure of acetylcholinesterase complexed with (-)galanthamine at 2.3 a resolution. FEBS Lett 463: 321326.

Greenwood D 1998. Galanthamine. A novel treatment for Alzheimer's disease. J Pharm Pharmacol Suppl 50: 20.

Grunwald J, Raveh L, Doctor B, Ashani Y 1994. Huperzine A as a pretreatment candidate drug against nerve agent toxicity. Life Sci 54: 991-997.

Guntern A, Ioset JR, Queiroz EF, Sandor P, Foggin CM, Hostettmann K 2003. Heliotropamide, a novel oxopyrrolidine-3-carboxamide from Heliotropium ovalifolium. J Nat Prod 66: 1550-1553.

Guo HY, Loren RR, Vanhutte PM 1992. Anisodamine inhibits acetylcholine-induced endothelium-dependent relaxation of canine femoral artery. Chin Med J 105: 666-670.

Gupta A, Gupta R 1997. A survey of plants for presence of cholinesterase activity. Phytochemistry 46: 827-831.

Harvey AL 1995. The pharmacology of galanthamine and its analogues. Pharmacotherapy 68: 113-128.

He XC, Yu CL, Bai DL 2003. Studies on analogues on huperzine A for treatment of senile dementia. Asymetric total synthesis of 14-nor-huperzine A and its inhibitory activity of acetylcholinesterase. Yao Hsueh Hsueh Pao 38: 346-349.

Hebert LE, Scherr PA, Beckeff LA 1995. Age-specific incidence of Alzheimer's Disease in a community population. JAMA 273: 1354-1359.

Hirasawa Y, Morita H, Shiro M, Kobayashi J 2003. Sieboldine A, a novel tetracyclic alkaloid from Lycopodium sieboldii, inhibiting acetylcholinesterase. Org Lett 5: 3991-3993.

Ho CC, Tasi HY, Lai YS, Chung JG 1999. Effects of the ellagic acid on the $N$-acetyltransferase activity and acetylation of 2-aminofluorene in the rat. Toxicol Environ Chem 71: 319-329.

Hogenauer K, Baumann K, Enz A, Mulzer J 2001. Synthesis and acetylcholinesterase inhibition of 5desaminohuperzine A derivatives. Bioorg Med Chem Lett 11: 2627-2630.

Howes MJR, Houghton PJ, Jenner P 1999. In-vitro screening for anticholinesterase activity of plants used traditionally for memory improvement. J Pharm Pharmacol Suppl 51: 238

Howes MJR, Perry NSL, Houghton PJ 2003. Plants with traditional uses and activities, relevant to the management of Alzheimer's disease and other cognitive disorders. Phytother Res 17: 1-18.

Hwang SY, Chang YP, Byun SJ, Jeon MH, Kim YC 1996. An acetylcholinesterase inhibitor isolated from Corydalis tuber and its mode of action. Korean J Pharmacogn 27: 91-95.

Ingkaninan $\mathrm{K}$, Temkitthawon $\mathrm{P}$, Chuenchom $\mathrm{K}$, Yuyaem $\mathrm{T}$, Thongnoi W 2003. Screening for acetylcholinesterase inhibitory activity in plants used in thai traditional rejuvenating and neurotonic remedies. $J$ Ethnopharmacol 89: 261-264.

Inokuchi II, Ohura M, Shimeno H, Okabe H, Yamaguchi T, Nagamatsu A, Nonaka G, Nishioka I 1987. Antihypertensive substance in seeds of Areca catechu L. J Pharmacobio Dyn 10: 62.

Itoh K, Ishige A, Hosoya E 1989. Cerebral function improvising drug containing a gomisin. Patent-PCT Int Appl-89 08, 451: 22pp.

Jang CH, Eun JS, Park HW, Seo SM, Yang JH, Leem KH, Oh SH, Oh CH, Baek NI, Kim DK 2003. An acetylcholinesterase inhibitor from the leaves of Securinega suffruticosa. Korean J Pharmacogn 34: 14-17.

Johnson N, Davis T, Bosanquet N 2000. The epidemic of Alzheimer's disease; how can we manage the costs? Pharmacoeconomics 18: 215-223.

Kalauni SK, Choudhari MY, Shaheen F, Manandhar MD, Rahman AU, Gewali MB, Khalid A 2001. Steroidal alkaloids from the leaves of Sarcococca coriacea of Nepalese origin. J Nat Prod 64: 842-844.

Kalauni SK, Choudhary MI, Khallid A, Manandhar MD, Dshaheen F, Rahman AU, Gewali MB 2002. New cholinesterase inhibiting steroidal alkaloids from the leaves od Sarcococca coriacea of Nepalese origin. Chem Pharm Bull 50: 1423-1426.

Khang SY, Lee KY, Sung SH, Park MJ, Kim Y C. 2001. Coumarins isolated from Angelica gigas inhibit acetylcholinesterase: structure-activity relationships. J Nat Prod 64: 683-685.

Kigoshi H, Kanematsu K, Yokota K, Uemura D 2000. Turbotoxins A and B, novel diiodotyramine derivatives from the Japanese gastropod Turbo marmorata. Tetrahedron 56: 9063-9070. 
Kim WG, Cho KM, Lee CK, Yoo ID 2002. Terreulactone A, a novel sesquiterpenoid with anti-acetylcholinesterase activity from Arpergillus terreus. Tetrahedron Lett 43: 3197-3198.

Korutla L, Kumar R 1994. Inhibitory effect of curcumin on epidermal growth factor receptor kinase activity in A431 cells. Biochem Biophys Acta 1224: 597-600.

Kozik MB, Maziarz LJ, Szczech J 1983. The effect of vincristina on the enzymatic activity in the brain. Folia Histochem Cytochem 21: 187-194.

Kozikowski AP, Yamada F, Tang XC, Hanin I 1990. Synthesis and biological evaluation of (+)-Z-huperzine A. Tetrahedron Lett 31: 6159-6162.

Kozikowski AP, Xia Y, Reddy ER, Tuckmantel W, Hanin I, Tang XC 1991a. Synthesis of huperzine A and its analogues and their anticholinesterase activity. $J$ Org Chem 56: 4636-4645.

Kozikowski AP, Miller CP, Yamada F, Pang YP, Miller JH, Mc-Kinney M, Ball RG 1991b. Delineating the pharmacophoric elements of huperzine A: importance of the unsaturated three-carbon bridge to its AChe inhibitory activity. J Med Chem 34: 3399-3402.

Kozikowski AP, Campain G, Saxena A, Doctor BP 1995. Synthesis and actylcholinesterase inhibitory activity of several pyrimidone analogues of Huperzine A. Chem Commun 283-285.

Kozikowski AP, Ding QJ, Sazena A, Doctor BP 1996. Synthesis of (+)-10,10-dimethylhuperzine A- a huperzine analogue possessing a slower enzyme off-rate. Bioorg Med Chem Lett 6: 259-262.

Kozubck A, Nietubyc M, Sikorski AF 1992. Modulation of the activities of membrane enzymes by cereal grain resorcinolic lipids. Z Naturforsch Ser C 47: 41-46.

Kumar R, Bansal RC, Mahmood A 1993. Isatin, na inhibitor of acetylcholinesterase activity in rat brain. Biogenic Amines 9: 281-284.

Kumar D, Mishra SK, Tripathi HC 2001. Mechanism of anthelmintic action of benzylisothiocyanate. Fitoterapia 62: 403-410.

Kuno F, Otoguro K, Shiomi K, Iwai Y, Omura S 1996.Arisugacins $\mathrm{A}$ and $\mathrm{B}$, novel and selective acetylcholinesterase inhibitors from Penicillium sp. J Antibiot 49: 742747.

Kurokawa T, Suzuki K, Hayaoka T, Nakagawa T, Izawa T, Kobayashi M, Harada N 1993. Cyclophostin, acetylcholinesterase inhibitor from Streptomyces lavendulae. J Antibiot 46: 1315-1318

Kvaltinova Z, Lukovic L, Machova J, Fatranska M 1991. Effect of steroidal alkaloid buxaminol $\mathrm{E}$ on blood pressure, acetylcholinesterase activity and $(3 \mathrm{H})$-quinuclidinyl benzilate binding in cerebral cortex. Pharmacology 43: 20-25.

Lahon LC, Singh N 1977. Pharmacologiacl study of Lawsonia inermis Linn. Indian J Physiol Pharmacol 22: 235 236.

Lee BH, Choi BW, Ryu GS, Kang KJ, Hwang DY, Hong ND 1997. Screening of the acetylcholinesterase inhibitors from medicinal plants. Korean J Pharmacogn 28: 167-173.

Li YM, Li Q, Sun M, Song GQ, Jiang SH, Zhu D 2004. ${ }^{1} \mathrm{H}$ NMR relaxation investigation of acetylcholinesterase inhibitors from huperzine A an derivative. Bioorg Med Chem Lett 14: 1585-1588.
Lin YC, Wu XY, Feng S, Jiang J, Luo JH, Zhou S, Vrijmoed LLP, Jones EBG, Krohn K, Steingrover K, Zsila F 2001. Five unique compounds: xyloketals from mangrove fungus Xylaria sp. from the South China sea coast. J Org Chem 66: 6252-6256.

Ling KH, Peng FC, Chen BJ, Wang Y, Lee GH 1986. Isolation, physicochemical properties and toxicities of of territrem A' and B'. Korean J Pharmacogn 17: 153 160.

Liu JS, Huang MF 1994. The alkaloids huperzines C and D and huperzinine from Lycopodiastrum casuarinoides. Phytochemistry 37: 1759-1761.

Liu JU, Zhang HY, Wang LM, Tang XC 1999. Inhibitory effects of huperzine $\mathrm{B}$ on cholinesterase activity in mice. Zhongguo Yaoli Xuebao 20: 141-145.

Mahanta M, Mukherjee AK 2001. Neutralisation of lethality, myotoxicity and toxic enzymes of naja kaouthia venom by Mimosa pudica root extracts. J Ethnopharmacol 75: 55-60.

Mahmoud MJ, Redha FMJM, Al-Azawi MJ, Hussein WA, Behnan YT 1987. Alkaloids of Iraqi Heliotropium ramosissimum: phytochemistry and some biochemical aspects. J Biol Sci Res 18: 127-135.

Man EMM, Peters WHM, Jansen JBMJ 1996. Effect of oltipraz, $\alpha$-tocopherol, $\beta$-carotene and phenethylisothiocyanate on rat esophageal, gastric, colonic and hepatic glutathione, glutathione-S-transferase and epoxidase. Carcinogenesis 17: 1439-1445.

Marston A, Kissling J, Hostettmann K 2002. A rapid TLC bioautographic method for the detection of acetylcholinesterase and butyrylcholinesterase inhibitors in plants. Phytochem Anal 13: 51-54.

Mc-Kinney M, Miller JH, Yamada F, Tuckmantel W, Kozikovski AP 1991. Potencies and stereoselectivities of enantiomers of huperzine A for inhibition of rat cortical acetylcholinesterase. Eur J Pharmacol 203: 303-305.

Miyazawa M, Watanabe H, Kameoka H 1997. Inhibition of acetylcholinesterase activity by monoterpenoids with a p-menthane skeleton. J Agr Food Chem 45: 677679.

Miyazawa M, Kakiuchi A, Watanabe H, Kameoka H 1998a. Inhibition of acetylcholinesterase activity by volatile $\alpha, \beta$-unsatured ketones. Nat Prod Lett 12: 131-134.

Miyazawa M, Yoshio K, Ishihawa Y, Kameoka H 1998b. Insecticidal alkaloids against Drosophilla melanogaster from Nuphar japonicum DC. J Agr Food Chem 46: 1059-1063.

Miyazawa M, Tougo H, Ishihara M 2001. Inhibition of acetylcholinesterase activity by essential oil from Citrus paradise. Nat Prod Lett 15: 205-210.

Morais LCSL, Barbosa-Filho JM, Almeida RN 2003. Plants and bioactives compounds for the treatment of Parkinson's desease. Arquivo de Fitomedicina 1: 127 132

Moura MD, Torres AR, Oliveira RAG, Diniz MFFM, BarbosaFilho JM 2001. Natural products inhibitors of models of mammary neoplasia. Brit J Phytotherapy 5: 124145.

Moura MD, Silva JS, Oliveira RAG, Diniz MFFM, BarbosaFilho JM 2002. Natural products reported as potential inhibitors of uterine cervical neoplasia. Acta Farm Bonaerense 21: 67-74. 
Mroue M, Alam M 1991. Crookshiine, a bisindole alkaloid from Haplophyton crooksii. Phytochemistry 30: 17411744.

Mroue MA, Ghuman MA, Alam M 1993. Crooksidine, na índole alkaloid from Haplophyton crooksii. Phytochemistry 33: 217-219.

Mroue MA, Euler KL, Ghuman MA, Alam M 1996. Indole alkaloids of Haplophyton crooksii. J Nat Prod 59: 890-893.

N'diaye I, Guella G, Mancini I, Pietra F 1996. Almazole D, a new type of antibacterial 2,5-disubstituted oxazolic dipeptide from a red alga of the coast of Senegal. Tetrahedron Lett 37: 3049-3050.

Ne'Eman I, Fishelson L, Kashman Y 1974. Sarcophine: a new toxin from the soft coral Sarcophyton glaucum (Alcyonaria). Toxicon 12: 593.

Nistri A, De-Bellis AM, Cammelli E, Pepeu G 1974. Effect of bicuculline, leptazol and strychnine on the acetylcholinesterase activity of the frog spinal cord in vivo. J Neurochem 23: 453.

Ogino T, Yamaguchi T, Sato S, Chin M 1992. Isolation of berbamine alkaloids from Stephania tetrandra as acetylcholinesterase inhibitors. Patent-Japan Kokai 159, 278: 10pp.

Ogino T, Yamaguchi T, Sato T, Sasaki H, Sugama K, Okada M, Maruno M 1997. Studies on inhibitory activity aginst acetylcholinesterase of new bisbenzylisoquinoline alkaloid and its related compounds. Heterocycles 45: 2253-2260.

Okamoto Y, Ojika M, Suzuki S, Murakami M, Sakagami Y 2001. Iantherans $\mathrm{A}$ and $\mathrm{B}$, unique dimeric polybrominated benzofurans as $\mathrm{Na}, \mathrm{K}-\mathrm{ATPase}$ inhibitors from a marine sponge, Ianthelia sp. Bioorg Med Chem 9: 179-183.

Omrua S, Kuno F, Otoguro K, Sunazuka T, Shiomi K, Masuma R, Iwai Y 1995. Arisugacin, a novel and selective inhibitor of acetylcholinesterase from Penicillium sp. $J$ Antibiot 48: 745-746.

Orhan I, Terzioglu S, Sener B 2003. a-Onocerin: an acetilcolinesterase inhibitor from Lycopodium clavatum. Planta Med 69: 265-267.

Orhan I, Sener B, Choudhary MI, Khalid A 2004 Acetylcholinesterase and butyrylcholinesterase inhibitory activity of some Turkish medicinal plants. J Ethnopharmacol 91: 57-60.

Otoguro K, Shiomi K, Yamaguchi Y, Arai N, Sunazuka T, Masuma R, Iwai Y, Omura S 2000. Arisugacins C and $\mathrm{D}$, novel acetylcholinesterase inhibitors and their related novel metabolites produced by Penicillium sp. $J$ Antibiot 53: 50-57.

Pak DW, Vogel III RW, Wenk GL 2001. Galanthamine: effect on nicotinic receptor binding, acetylcholinesterase inhibition and learning. Proc Nat Acad Sci (USA) 98: 2089-2094

Park CH, Kim SH, Choi W, Lee YJ, Kim JS, Kang SS, Suh YH 1996. Novel anticholinesterase and antiamnesic activities of dehydroevodiamine, a constituent of Evodia rutaecarpa. Planta Med 62: 405-409.

Peng FC 1995. Acetylcholinesterase inhibition by territrem B derivatives. J Nat Prod 58: 857-862.

Peng WD, Xu SB, Peng X 1996. Inhibitory effect of suberogorgin on acetylcholinesterase. Acta Pharmacol Sin 17: 369372.

Pereira JV, Modesto-Filho J, Agra MF, Barbosa-Filho JM 2002.
Plant and plant-derived compounds employed in prevention of the osteoporosis. Acta Farm Bonaerense 21: 223-234.

Permtermsin C, Chantong B, Ongpipattanakul B, Chaichanthipyuth C, Lipipun V, Meksuriyen D 2001. Inhibition of acetylcholinesterase by barakol. Thai $J$ Pharm Sci 25: 29.

Perry NSL, Houghton PJ, Theobald A, Jenner P, Perry EK 2000. In-vitro inhibition of human erythrocyte acetylcholinesterase by Salvia lavandulaefolia essential oil and constituent terpenes. J Pharm Pharmacol 52: 895-902.

Perry NSL, Houghton PJ, Jenner P, Keith A, Perry EK 2002. Salvia lavandulaefolia essential oil inhibits cholinesterase in vivo. Phytomedicine 9: 48-51.

Prozorovskii VB, Velikova VD, Pshenkina NN, Vasilenko ET 1996. Comparative clinico-experimental characteristics of aminostigmine and galanthamine used for treatment of poisoning with cholino-blocking substances. Eksp Klin Farmakol 59: 64-67.

Racchi M, Mazzucchelli M, Porrello E, Lanni C, Govoni S 2004. Acetylcholinesterase inhibitors: novel activities of old molecules. Pharmacol Res 50: 441-451.

Rahman AU, Parveen S, Khalid A, Farooq A, Ayattollahi SAM, Choudhary MY 1998. Acetylcholinesterase inhibiting triterpenoidal alkaloids from Buxus hyrcana. Heterocycles 49: 481-488.

Rahman AU, Fatima N, Akhtar F, Choudhary MI, Khalid A 2000. New norditerpenoid alkaloids from Aconitum falconeri. J Nat Prod 63: 1393-1395.

Rahman AU, Parveen S, Khalid A, Farooq A, Choudhary MI 2001. Acetyl and butyrylcholinesterase-inhibiting triterpenoid alkaloids from Buxus papillosa. Phytochemistry 58: 963-968.

Rahman AU, Haq ZU, Khalid A, Anjum S, Khan MR, Choudary MI 2002a. Preganane-type steroidal alkaloids of Sarcococca saligna: a new class of cholinesterase inhibitors. Helv Chim Acta 85: 678-687.

Rahman AU, Akhtar MN, Choudhary MI, Tsuda Y, Sener B, Khalid A, Parvez M 2002b. New steroidal alkaloids from Fritilaria imperialis and their cholinesterase inhibiting activities. Chem Pharm Bull 50: 10131016.

Rahman AU, Feroz F, Hao ZU, Nawaz SA, Khan MR, Choudhary MI 2003. New steroidal alkaloids from Sarcococca saligna. Nat Prod Res 17: 235-241.

Rajendran V, Prakash KRC, Ved HS, Saxena A, Doctor BP, Kozikowski AP 2000. Synthesis, chiral chromatographic separation and biological activities of the enatiomers of 10,10-dimethylhuperzine A. Bioorg Med Chem Lett 10: 2467-2469.

Rasomiaranjanahary L, Guilet D, Marston A, Randimbivololona F, Hostettmann K 2003. Antifungal isopimaranes from Hypoestes serpens. Phytochemistry 64: 543-548.

Reddy MVR, Lakshman S, Rao AVR., Venkateswarlu Y, Rao JV A new diterpene from a soft coral, Sinularia dissecta. J Nat Prod 56: 970-972.

Rhee IK, Meent MV, Ingkaninan K, Verpoorte R 2001. Screening for acetylcholinesterase inhibitors from Amaryllidaceae using silica gel thin-layer chromatography in combination with bioactivity stainin. J Chromatogr A 915: 217-223.

Rhee IK, Appels N, Luijendijk T, Irth H, Verpoorte R 2003. 
Determining acetylcholinesterase inhibitory activity in plant extract using a fluorimetric flow assay. Phytochem Anal 14: 145-149.

Rocha LG, Almeida JRGS, Macedo RO, Barbosa-Filho JM 2005. A review of natural products with antileishmanial activity. Phytomedicine 12: 514-535.

Salvati S, Attorri L, Felice MD, Campeggi LM, Pintor A, Toburzi F, Tomassi G 1996. Effect of dietary cells on brain enzymatic activities $(2$ ', 3'-cyclic nucleotide 3'-phosphodiesterase and acetylcholinesterase) and muscarinic receptor. J Nutr Biochem 7: 113-117.

Schmeller T, Bruning BL, Wink M 1997. Biochemical activities of berberine, palmatine and sanguinarine mediating chemical defense against microorganisms and herbivores. Phytochemistry 44: 257-266.

Schneider LJ 2001. Treatment of Alzheimer's disease with cholinesterase inhibitors. Clin Geriatr Med 17: 337339.

Sener R 2002. Molecular diversity in the alkaloids of Turkish Fumaria L. species. Acta Pharm Turc 44: 205-212.

Sharifi AM, Darabi R, Akbarloo N 2003. Investigation of antihypertensive mechanism of garlic in hypertensive rat. J Ethnopharmacol 86: 219-224.

Shimosaka Y 1955. Pharmacologiacl action of deoxynupharidine hydrochloride, a component of Nuphar japonicum. Ann Rep Fac Pharm Kanazawa Univ 5: 40.

Shin DH, Yu H, Hsu WH 1993. A paradoxical stimulatory effect of berberine on guinea-pig ileum contractily: possible, involvement of acetylcholine release from the postganglionic parasympathetic nerve and cholinesterase inhibition. Life Sci 53: 1495-1500.

Silva JS, Moura MD, Oliveira RAG, Diniz MFFM, BarbosaFilho JM 2003. Natural products inhibitors of ovarian neoplasia. Phytomedicine 10: 221-232.

Singh DK, Agarwal RA 1984. Correlation of the anticholinesterase and moluscicidal activity of the latex of Euphorbia royleana on the snail Lymnaea acuminate. J Nat Prod 47: 702-705.

Singh VK, Singh DK 1996. Enzyme inhibition by allicin, the moluscicidal agent of Allium sativum L. (Garlic). Phytother Res 10: 383-386.

Singh VK, Singh S, Singh S, Singh DK 1999. Effect of active molluscicidal component of spices on different enzyme activities and biogenic amine levels in the nervous tissue of Lymnaea acuminata. Phytother Res 13: 649-654.

Siqueira IR, Fochesatto C, Silva AL, Nunes DS, Battastini AM, Alexandre-Netto C, Elisabetsky E 2003. Ptychopetalum olacoides, a traditional Amazonian "nerve tonic", possesses anticholinesterase activity. Pharmacol Biochem Be 75: 645-650.

Stryer L 1995. Biochemistry. 4th ed., WH Freeman: San Francisco, CA, p. 1017.

Suga T, Ohta S, Munesada K, Ide N, Kurokawa M, Shimizu M, Ohta E 1993. Endogenous pine wood nematicidal substances in pines, Pinus massoniana, $P$. strobes and P. palustris. Phytochemistry 33: 1395-1401.

Sung SH, Kang SY, Lee KY, Park MJ, Kim JH, Park JH, Kim YC, Kim J, Kim YC 2002. (+)- $\alpha$-Vinifrin, a stilbene trimer from Caragana chamlague, inhibits acetylcholinesterase. Biol Pharm Bull 25: 125-127.

Tai K, Shen T, Henchman RH, Bourne Y, Marchot P. McCammon JA2002. Mechanism of acetylcholinesterase inhibition by fasciculin: a 5-NS molecular dynamic simulation. $J$ Amer Chem Soc 124: 6153-6161.

Takayama H, Katakawa K, Kitajima M, Seki H, Yamaguchi K, Aimi N 2001. A new type of lycopodium alkaloid, lycoposerramine A, from Lycopodium serratum Thunb. Org Lett 3: 4165-4167.

Tan CH, Jiang SH, Zhu DY 2000. Huperzine P, a novel lycopodium alkaloid from Huperzia serrata. Tetrahedron Lett 41: 5733-5736.

Tan CH, Chen GF, Ma XQ, Jiang SH, Zhu DY 2002. Huperzine $\mathrm{R}$, a novel 15-carbon lycopodium alkaloid from Huperzia serrata. J Nat Prod 65: 1021-1022.

Tang XC, Kindel GH, Kozikowski AP, Hanin I 1994. Comparison of the effects of natural and synthetic huperzine $\mathrm{A}$ on rat brain cholinergic function in vitro and in vivo. J Ethnopharmacol 44: 147-155.

Thomas PLB, Pal AK 1974. Insecticidal activity of garlic oil II. Mode of action of the oil as a pesticide in musca domestic nebulo and Trogoderma granarium. J Food Sci Technol 11: 153-158.

Tilyabaev Z, Abduvakhabov AA 1998. Alkaloids od Anabasis aphylla and their cholinergic activities. Chem Nat Comp 34: 295-297.

Tonkopii VD, Prozorovskii VB 1976. Study of the reaction of galanthamine with tha acetylcholinesterase of the mouse brain in vivo. Bull Eskp Biol Med 82: 823.

Trevisan MTS, Macedo FVV 2003. Seleção de plantas com atividade anticolinesterase para tratamento da doença de Alzheimer. Quim Nova 26: 301-304.

Turk T, Macek P, Suput S 1995. Inhibition of acetylcholinesterase by a pseudozoanthoxanthin-like compound isolated from the zoanthid Parazoanthus axinellae (O. Schmidt). Toxicon 33: 133-142.

Tyutyulkova N, Tuneva S, Goranthcheva U, Zhivkov V, Chelibonova-Lorer H, Bozhkov S 1981. Hepatoprotective effect of silymarin (carsil) on liver of $D$-galactosamine-treated rats. Biochemical and morphological investigations. Method Find Exp Clin Pharmacol 3: 71-77.

Ulrichova J, Walterova D, Preininger V, Slavik J, Lenfeld J, Cushman M, Simanek V 1983. Isoaltion, chemistry and biology of alkaloids from plants of the Papaveraceae. Inhibition of acetylcholinesterase activity by some isoquinoline alkaloids. Planta Med 48: 111-115.

Ulrichova J, Walterova D, Simanek V 1984. Molecular mechanisms of the biological activity of quaternary benzophenanthridine and protoberberine alkaloids. Acta Univ Palacki Olomuc Fac Med 106: 31-37.

Ulrichova J, Kovar J, Simanek V 1985. Interaction of quaternary aromatic isoquinoline alkaloids with acetylcholinesterase from electrophorus electricus. Collect Czech Chem Commun 50: 978-982.

Ulrichova J, Lenfeld J, Cushman M, Mohan P, Simanek P 1986. Comparison of biological activity of some benzo-[C]phenanthridine alkaloids and their structural analogs. Acta Univ Palacki Olomuc Fac Med 113: 401-407.

Van-Wagenen BC, Larsen R, Cardellina JH, Randazzo D, Lidert ZC, Swithenbank C 1993. Ulosantoin, a potent insecticide from the Sponge ulosa Ruetzler. J Org Chem 58: 335-337.

Viegas-Junior C, Bolzani VS, Furlan M, Fraga CAM, Barreiro EJ 2004. Produtos naturais como candidatos a fármacos úteis no tratamento do mal de Alzheimer. 
Quim Nova 27: 655-660

Wang B, He XC, Bai DL 1999. Studies on analogues of huperzine A for treatment of senile dementia. Synthesis of optically active (-)-1-methyl huperzine A. Yao Hsueh Hsueh Pao 34: 434-438.

Wang LM, Han YF, Tang XC 2000. Huperzine A improves cognitive deficits caused by chronic cerebral hypoperfusion in rats. Eur J Pharmacol 398: 65-70.

Wekell JC, Liston J 1978. The isolation and characterization of a toxic diterpenoid compound from the sea pen, Ptilosarcus gurneyi (Gray). Diss Abstr Int B 39: 2210.

Welch C, Wuarin L, Sidell N 1992. Antiproliferative effect of the garlic compound S-allyl cysteine on human neuroblastoma cells in vitro. Cancer Lett 63: 211219.

Written SJ, Fenical W, Faulkner DJ, Wekell JC 1977. Pilosarcone, the toxin from the sea pen Ptilosarcus gurneyi. Tetrahedron Lett 1559.

Wu C, Yu Q 1984. Pharmacological studies on Bupleurum chinense and its active ingredient, crude saikosaponin. Shenyang Yaоxueyuan Xuebao 1: 214-218.

Xu SB, Peng WD, Hu YT, Wang YF 1992. Excitory effect of sodium suberogorgin on isolated rabbit ileum. Acta Pharmacol Sin 13: 459-463.

Yamada F, Kozikowski AP, Reddy ER, Pang YP, Miller JH, McKinney M 1991. A route to optically pure (-)-huperzine A: molecular modeling and in vitro pharmacology. $J$ Amer Chem Soc 113: 4695-4696.

Yu QS, Atack JR, Rapoprt SI, Brossi A 1988. Synthesis and anticholinesterase activity of (-)-norphysostigmine, ()-eseramine and other $N(1)$-substituted analogues of (-)-physostigmine. J Med Chem 31: 2297-2300.

Yu KW, Kim KM, Suh HJ 2003. Pharmacological activities of stromata of Cordyceps scarabaecola. Phytother Res 17: 244-249.

Zarotsky V, Sramek JJ, Cutler NR 2003. Galanthamine hydrobromide: an agent for Alzheimer's disease. $\mathrm{Am}$ $J$ Health-System Pharmacist 60: 446-452.

Zhang X, Chiu SF 1992. Effects of toosendanin on several enzyme systems of the cabbage worm Pieris rapae $\mathrm{L}$. Kunchong Xuebao 35: 171-177.

Zhang Q, Tang XC 2002a. Effects of huperzine A on acetylcholinesterase isoforms in vitro: comparison with tacrine, donezepil, rivastigmine and physostigmine. Eur J Pharmacol 455: 101-107.

Zhang HY, Liang YQ, Tan XC, He XC, Bai DL 2002b. Stereoselectivities of enantiomers of huperzine $\mathrm{A}$ in protection against $\beta$-amyloid-25,35-induced injury in PC12 and NG108-15 cells and cholinesterase inhibition in mice. Neurosci Lett 317: 143-146.

Zhu ZP, Xie RM, Zhou PF, Miao AR, Shen YQ, Chen GJ, Ma SD 1982. Pharmacology of active components of Thermopsis lanceolata. Shan-His Hsin I Yao 11: 5354. 


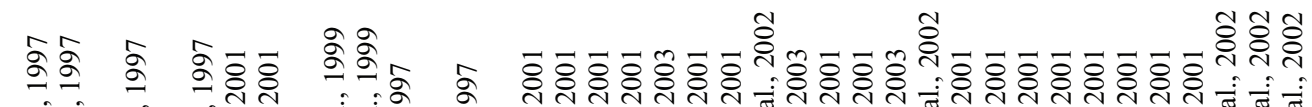

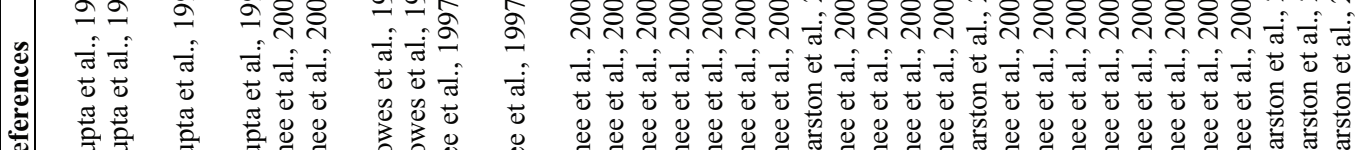

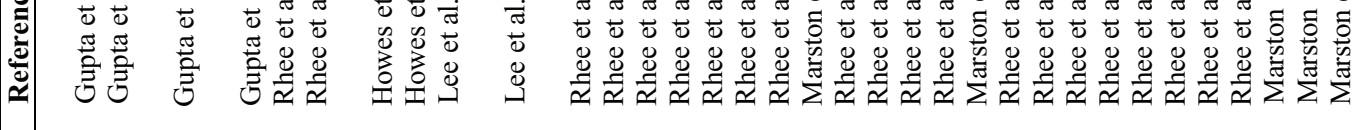

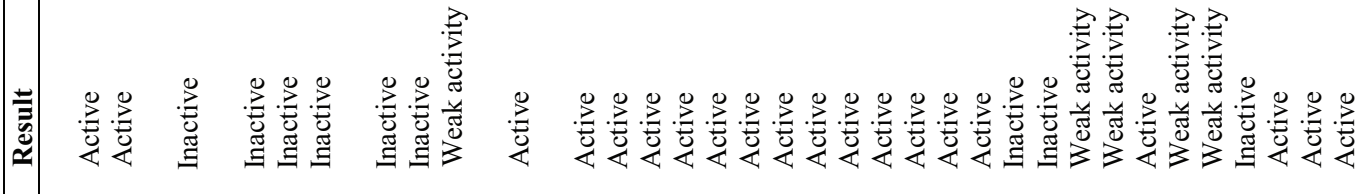

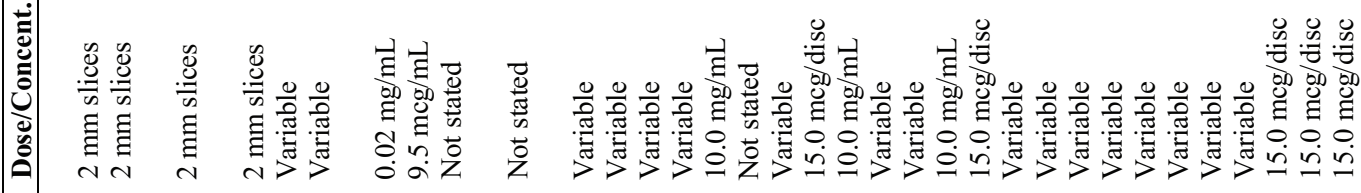

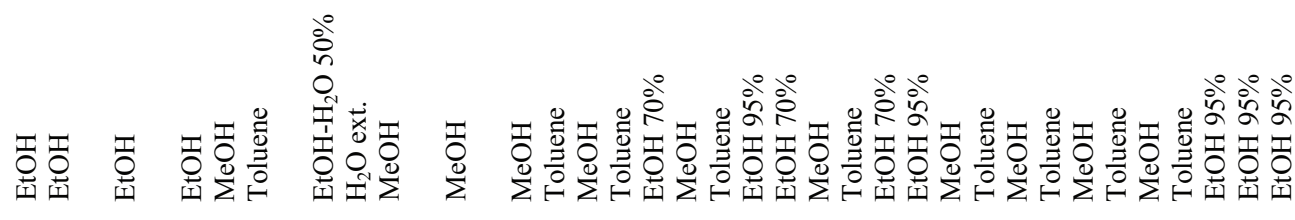

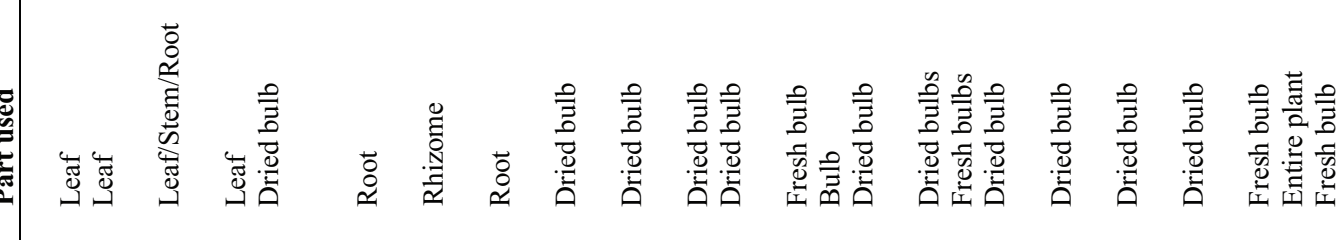

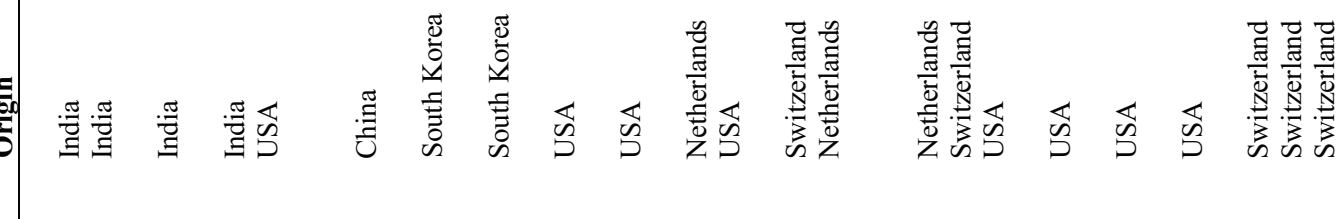




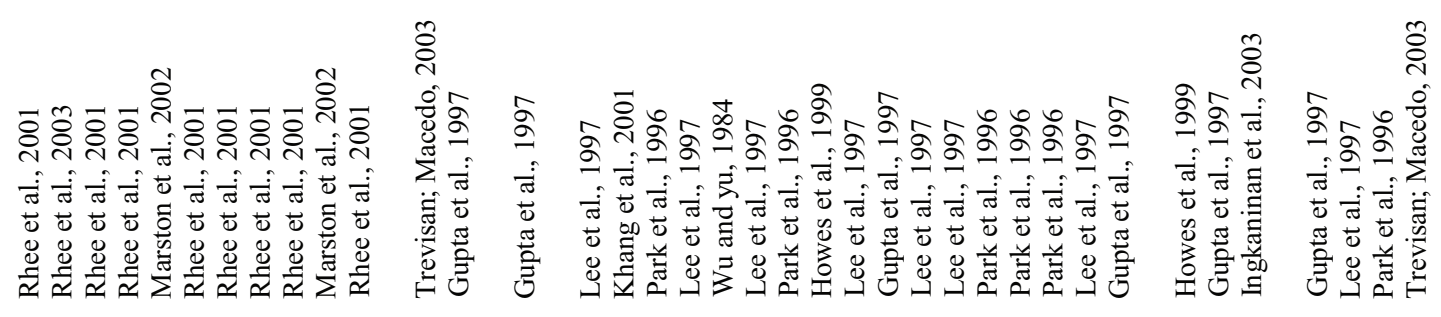

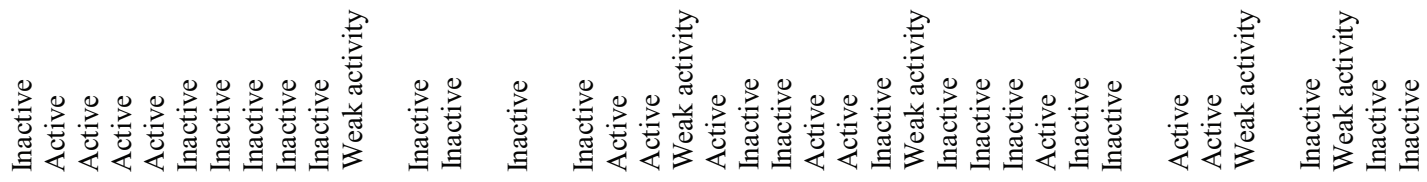

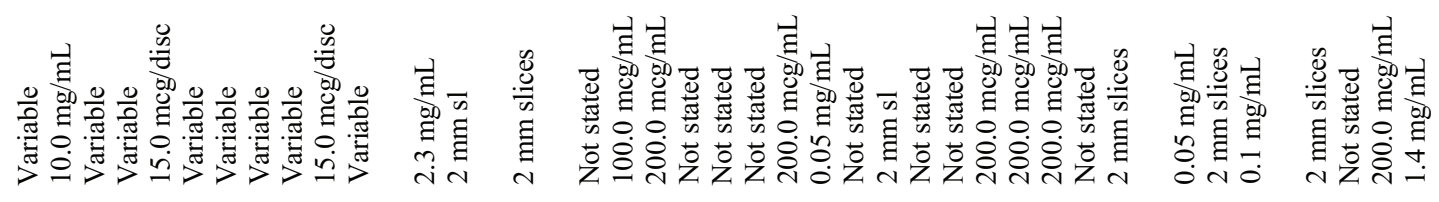

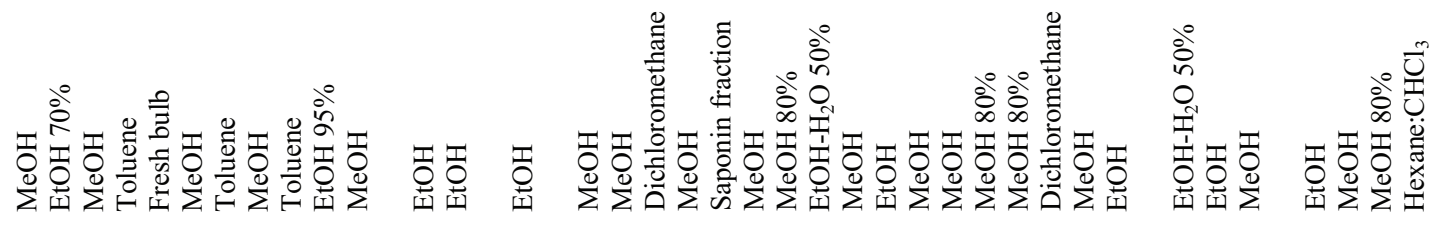

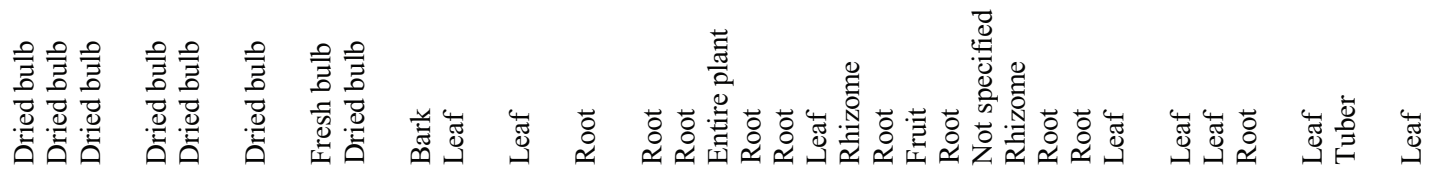

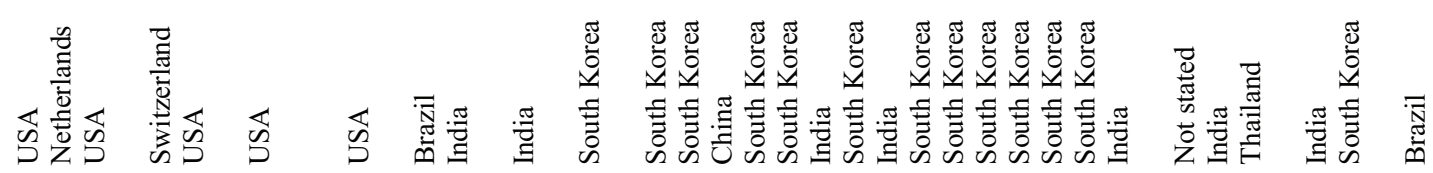

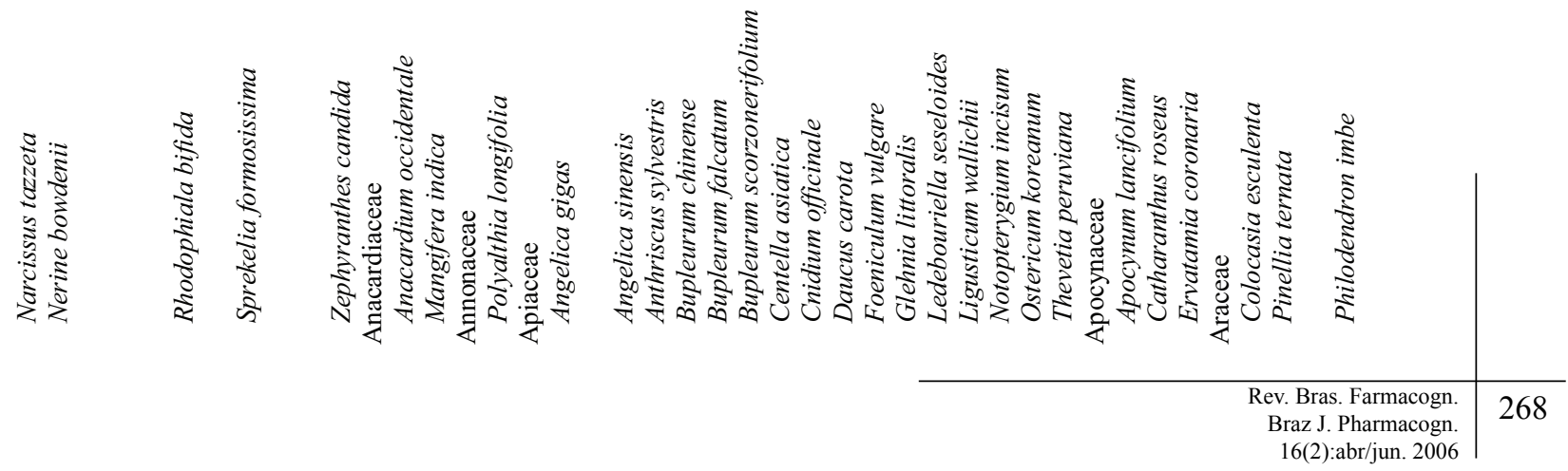




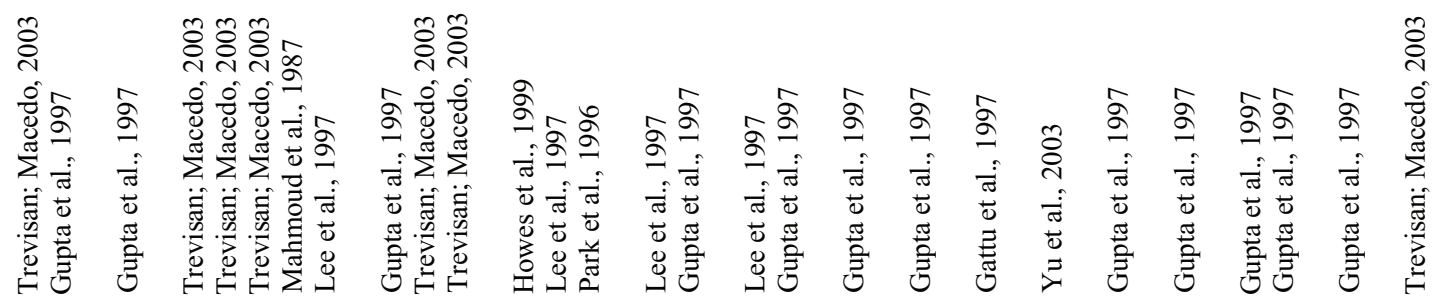

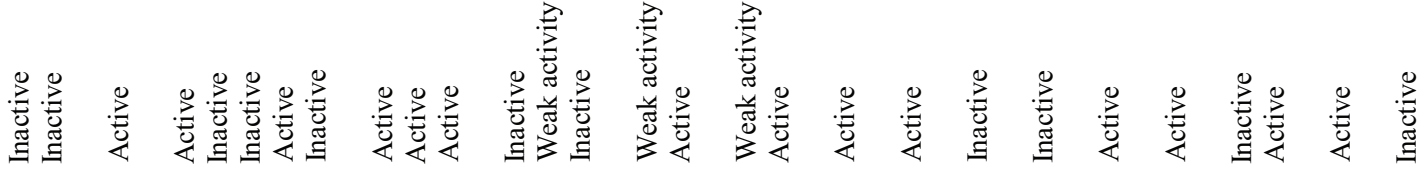

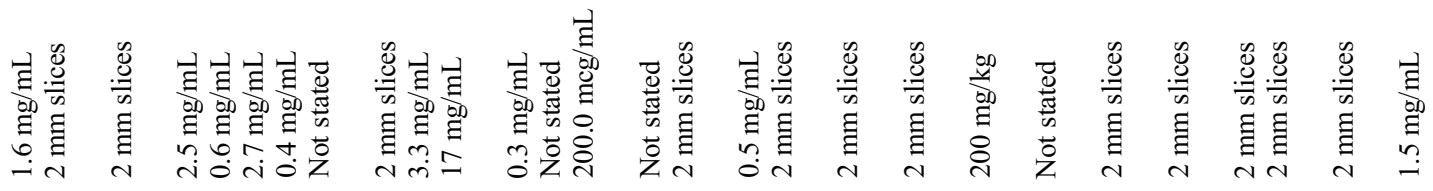

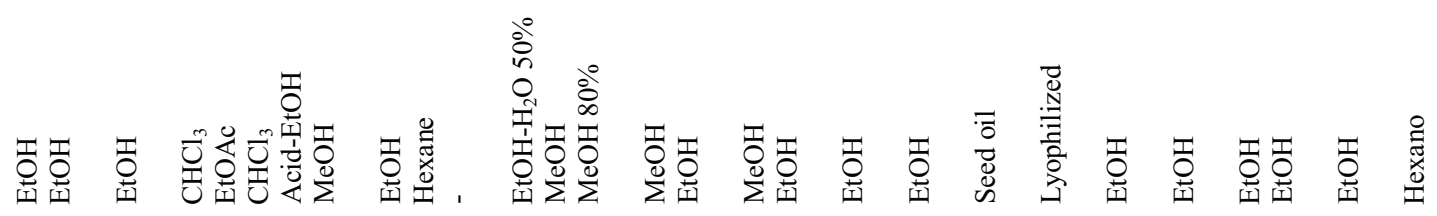

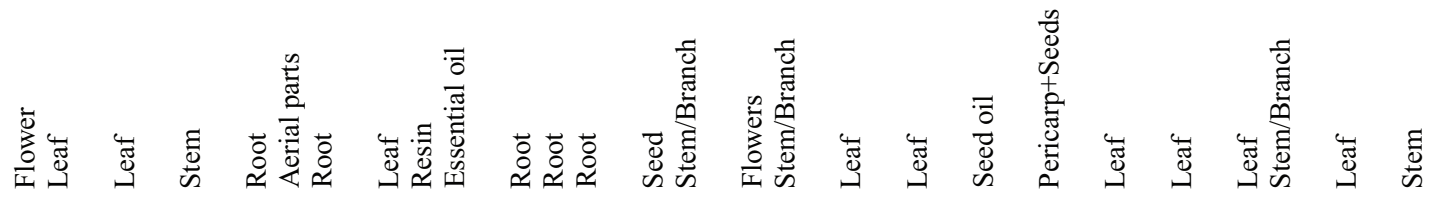

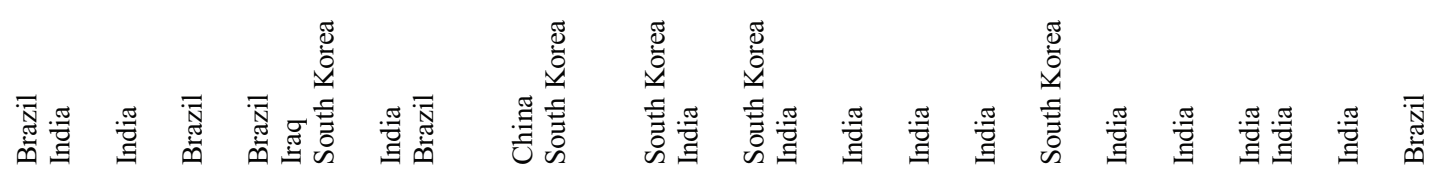

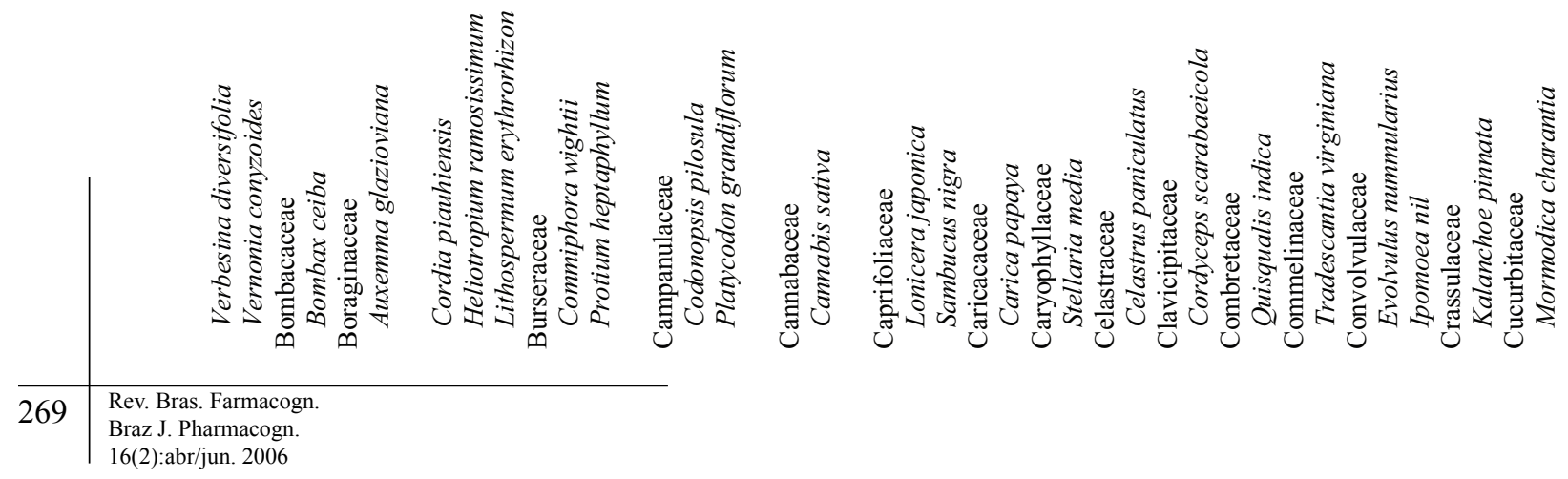




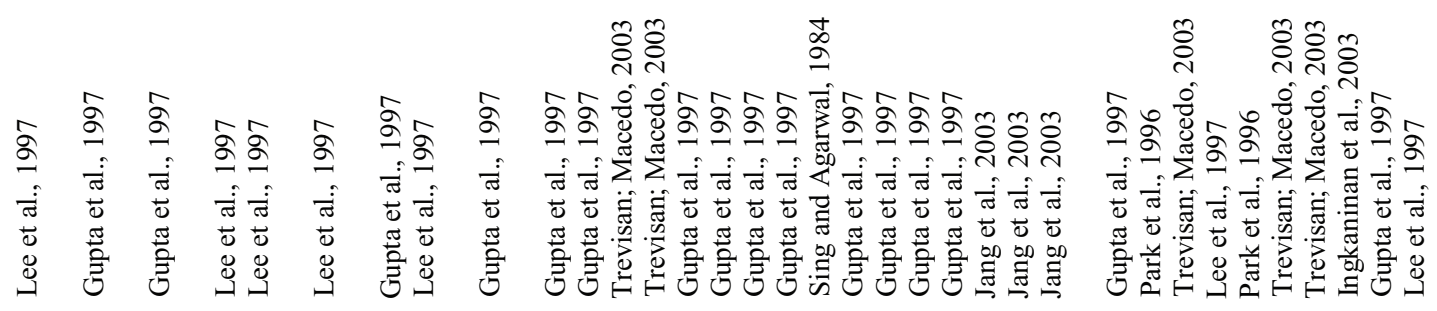

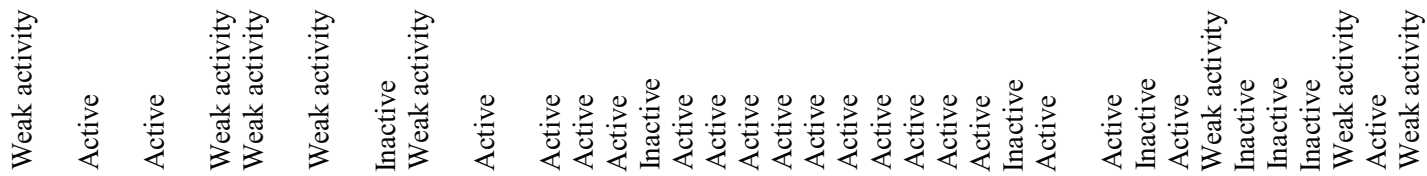

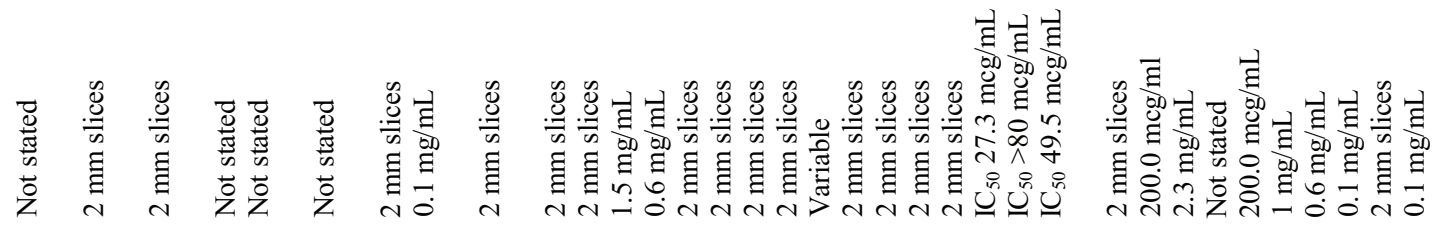

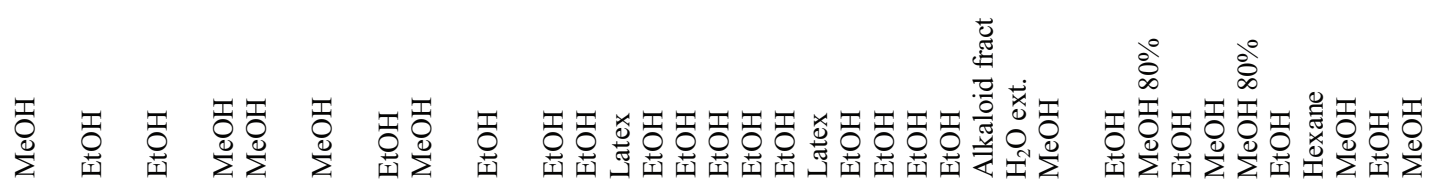

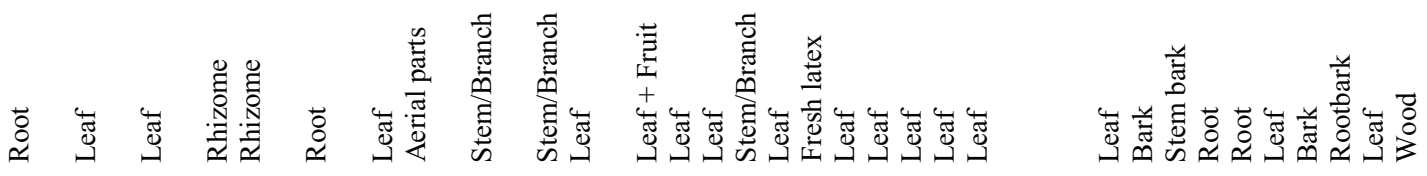

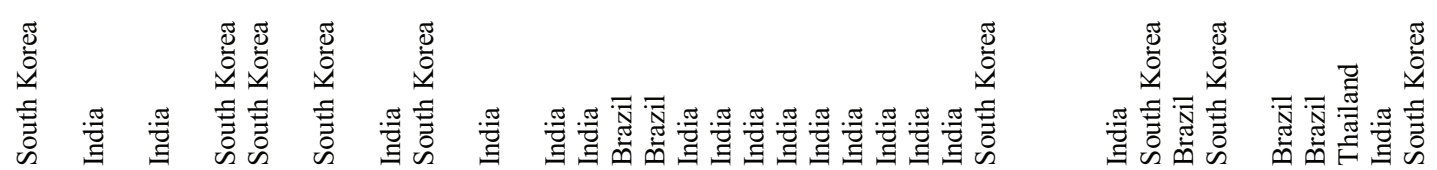

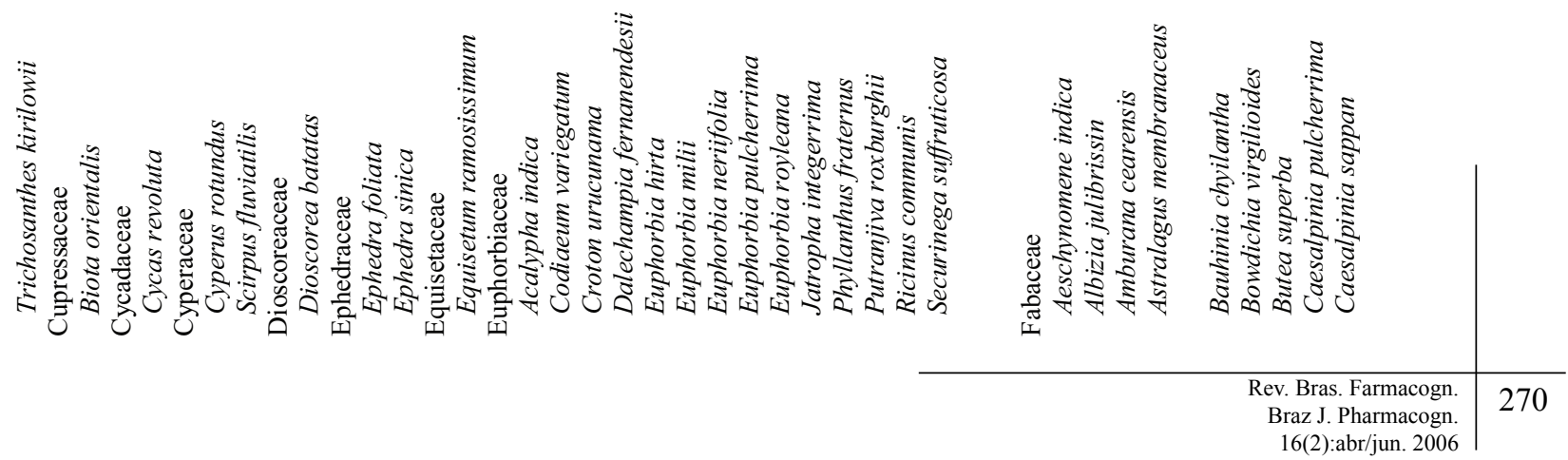




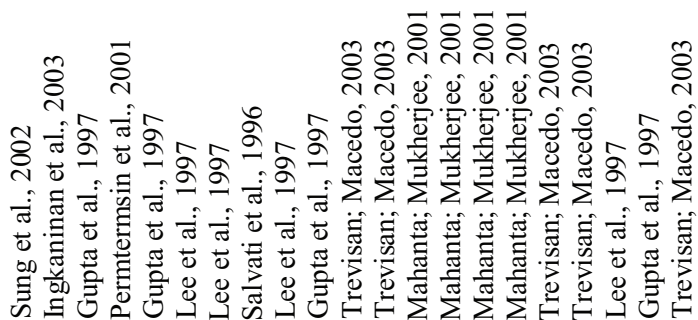

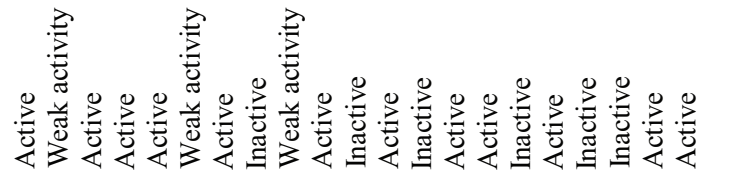

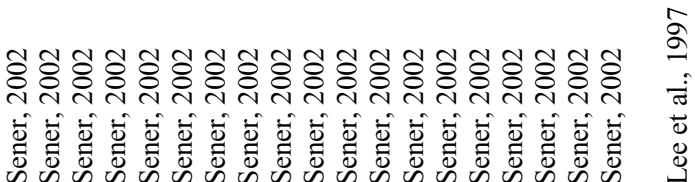

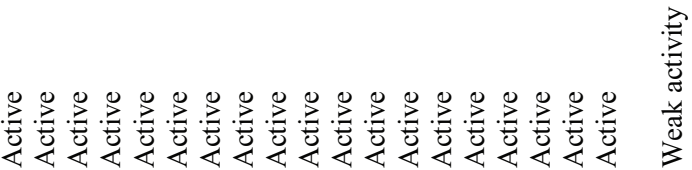

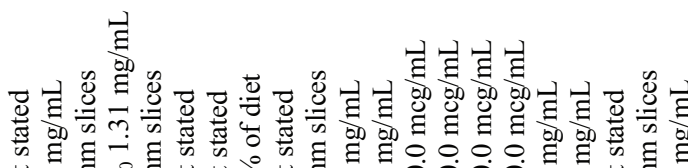

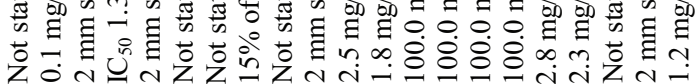

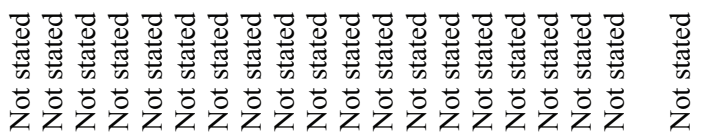

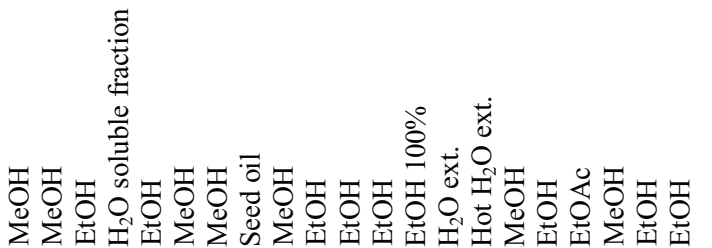

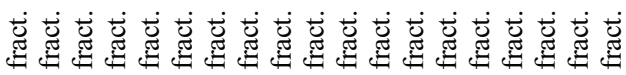

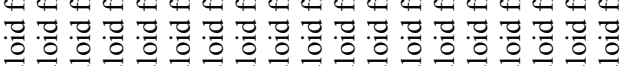

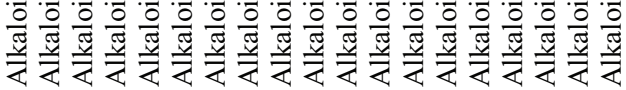

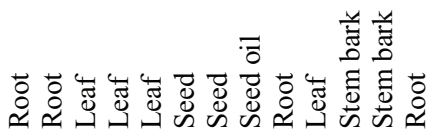<smiles>C1C2C3C4C1C1C2C3C41</smiles>

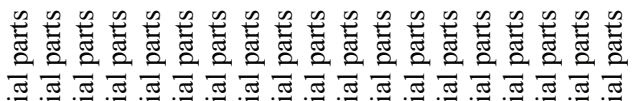

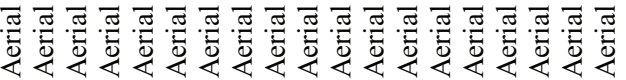
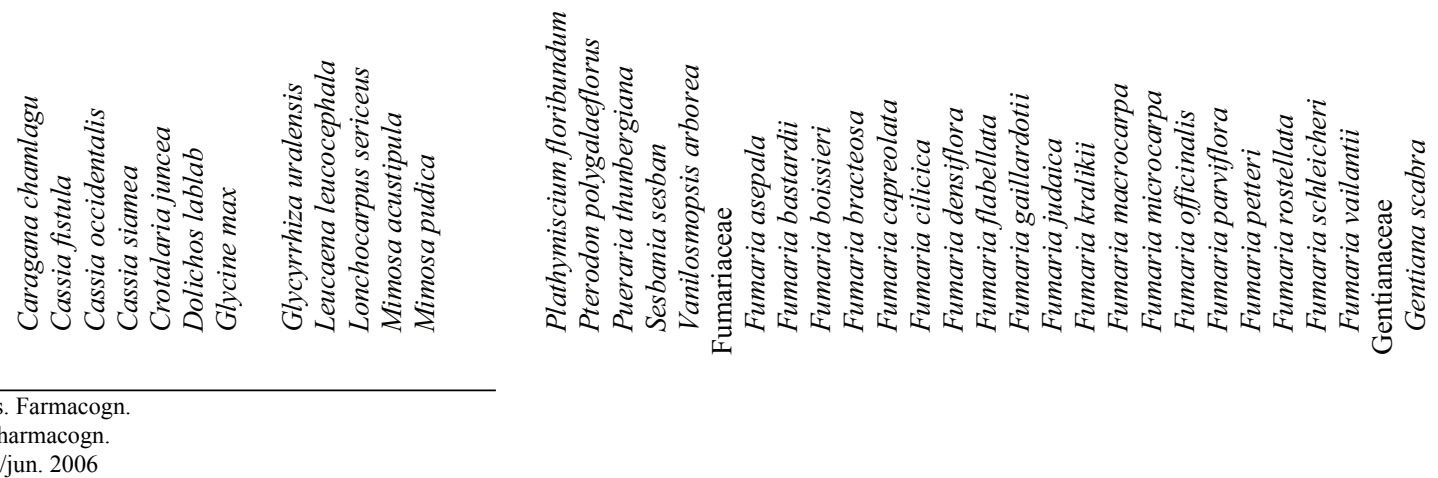


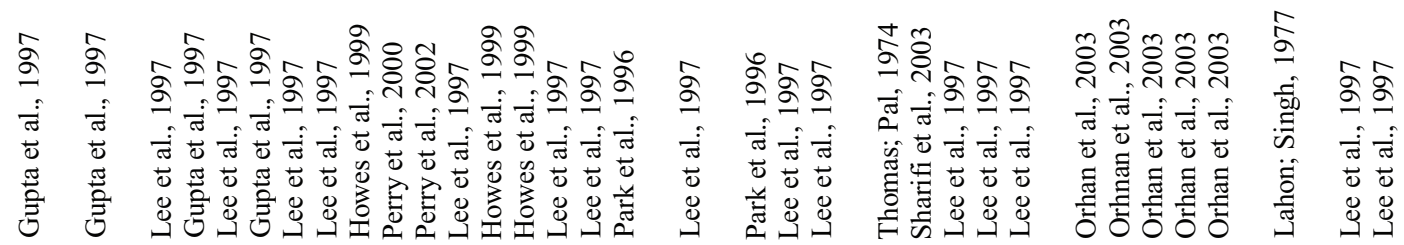

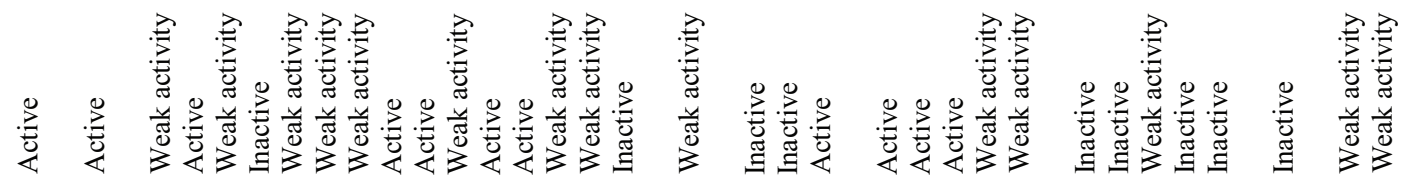

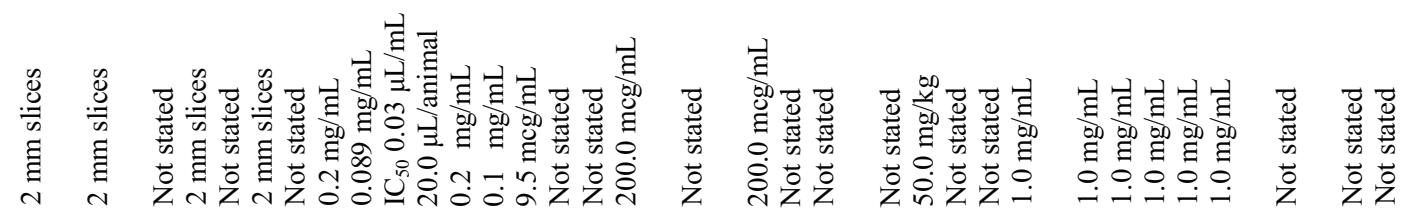

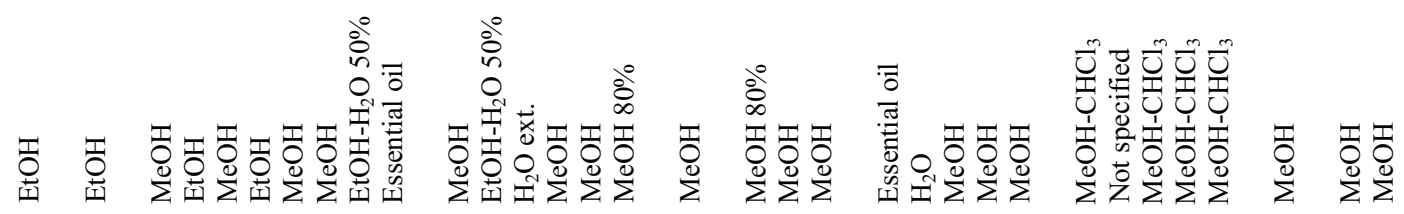

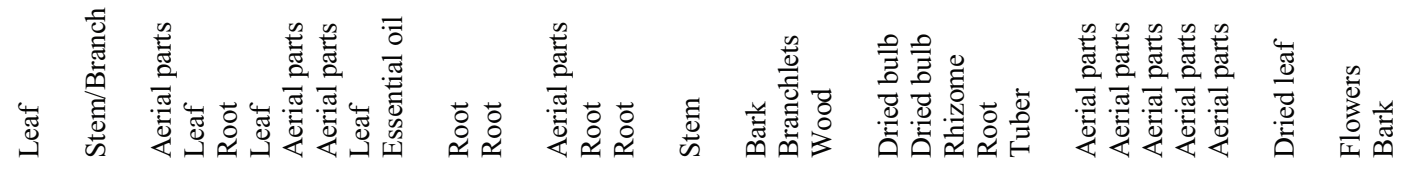

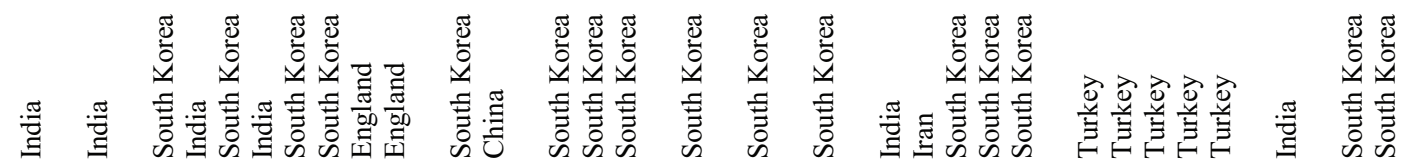
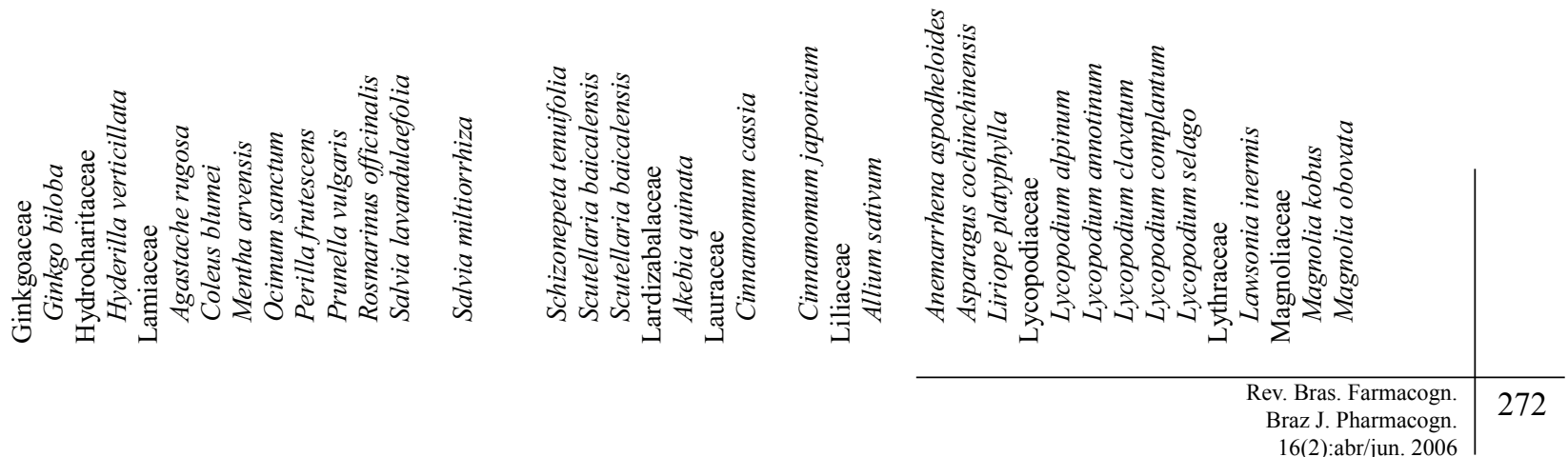


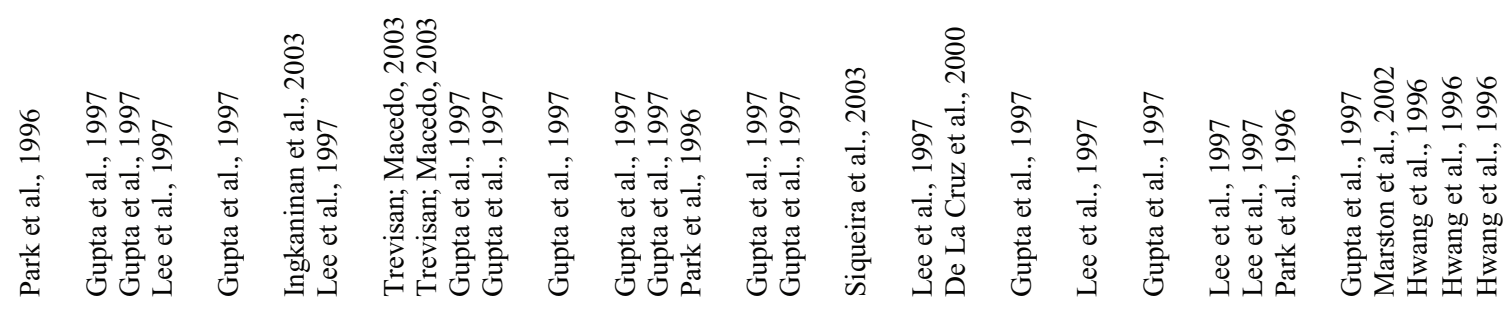

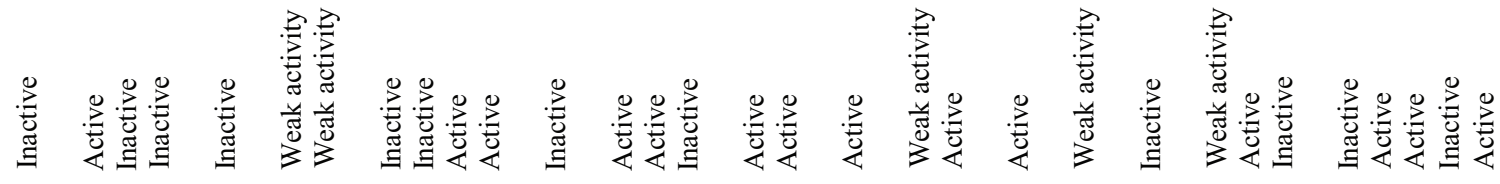

Mn

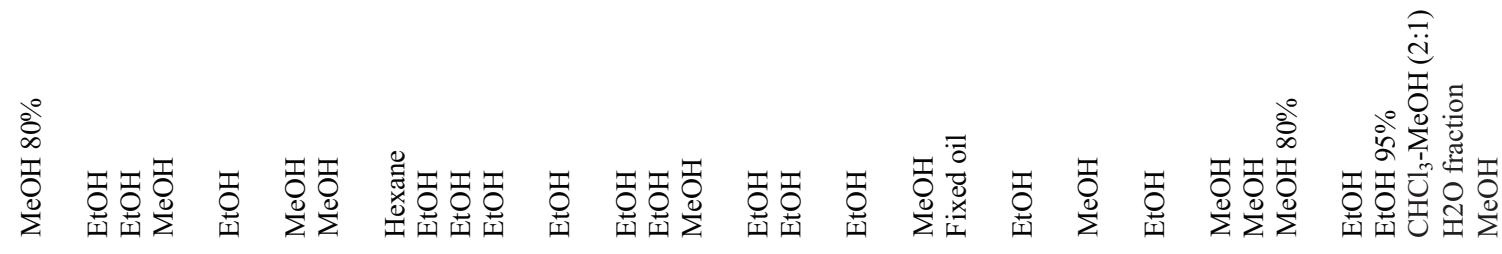

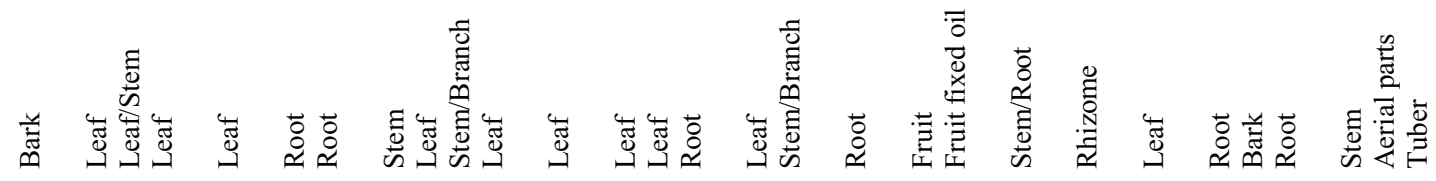

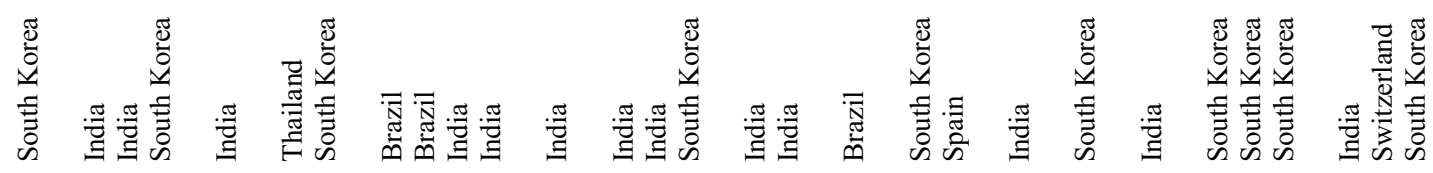

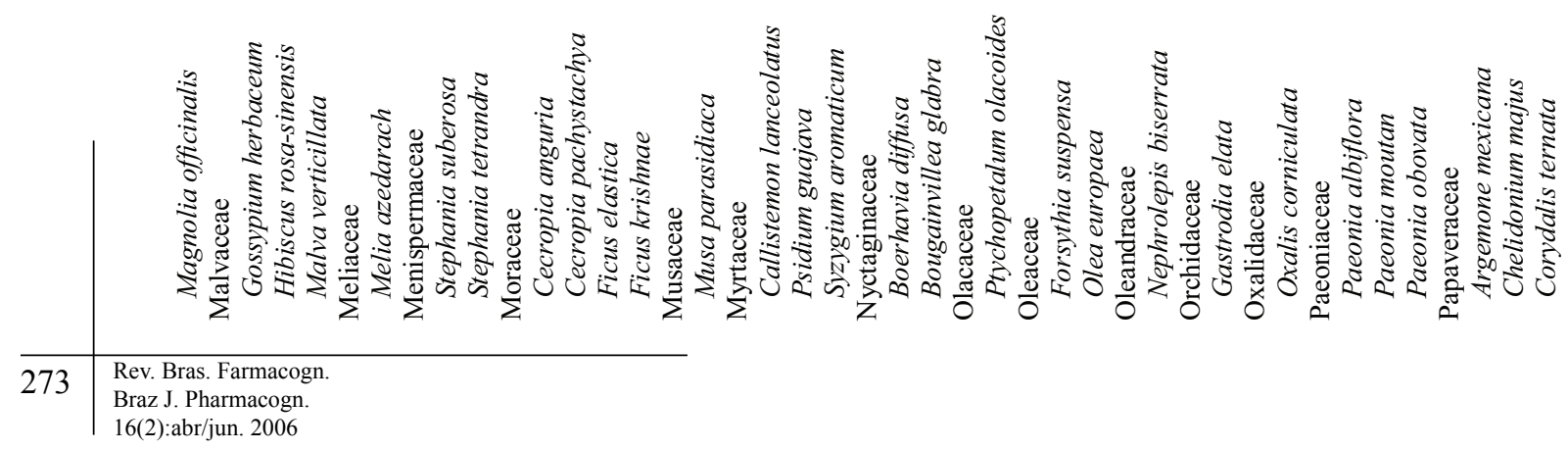


क्ठ융

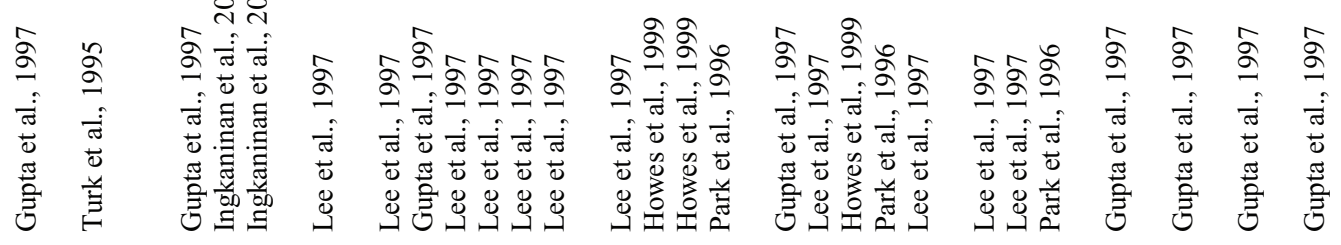

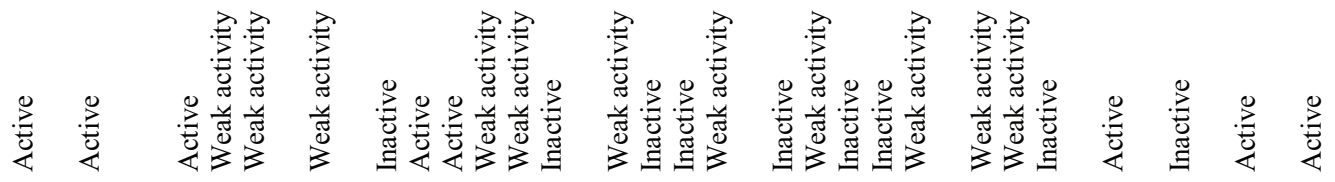

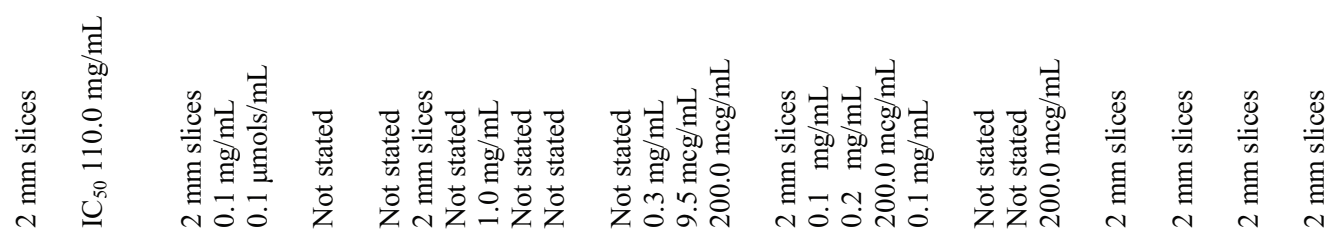

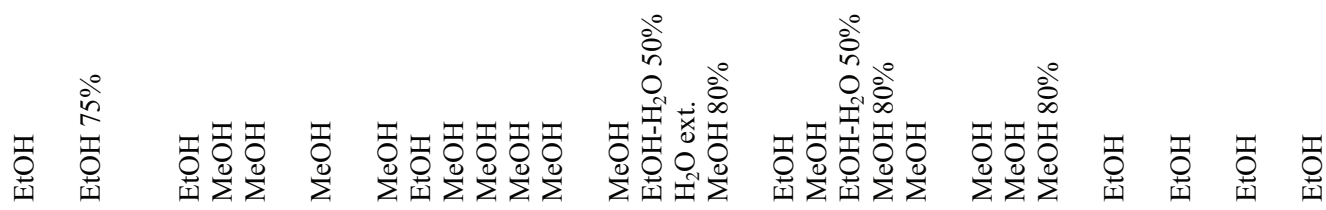

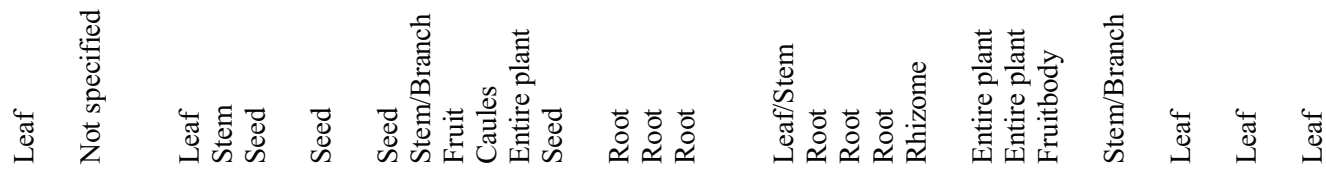

总

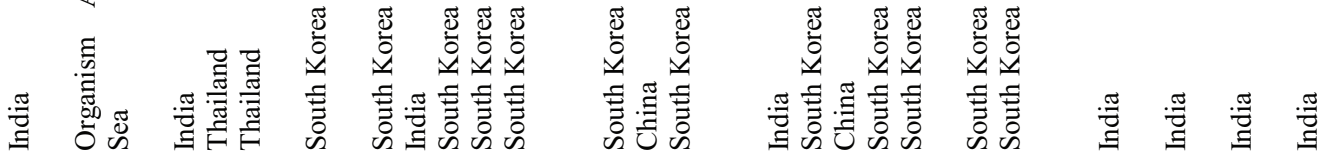

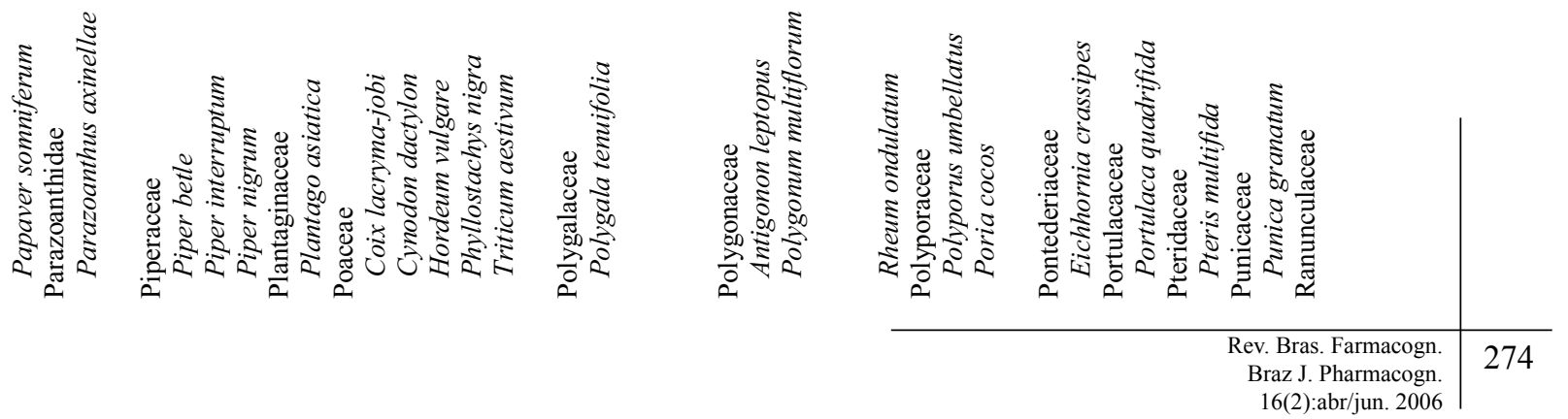




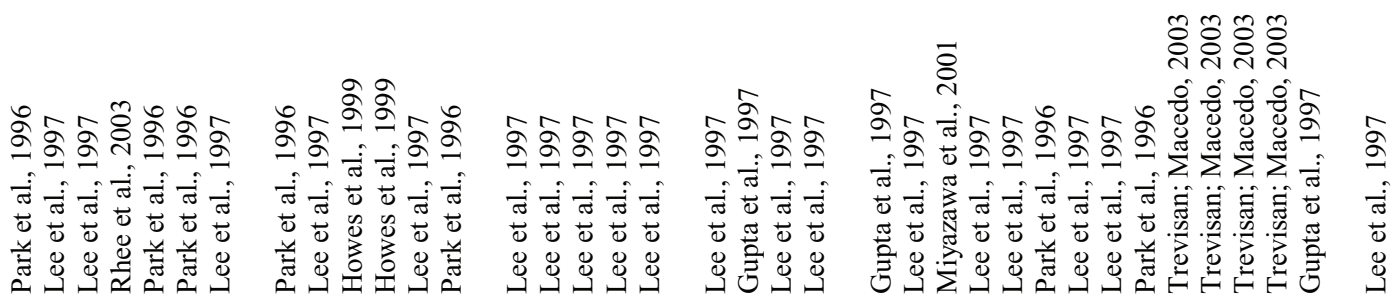

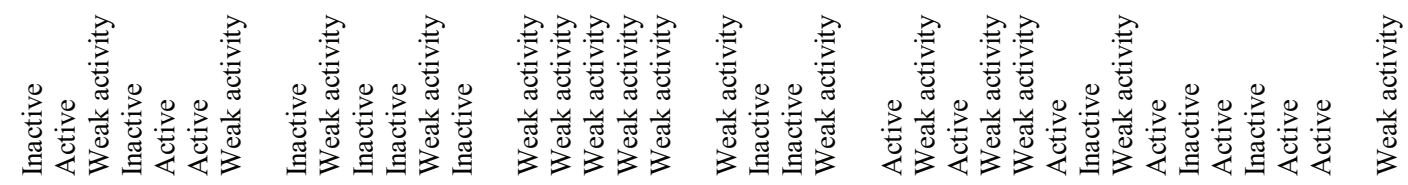

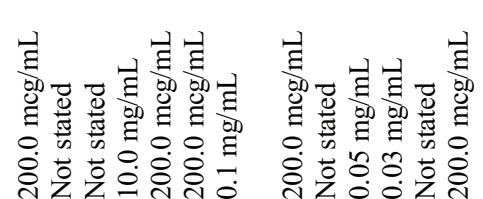

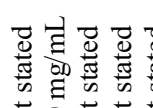

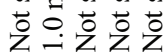

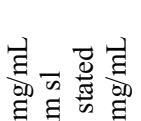

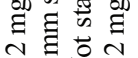
ป艹

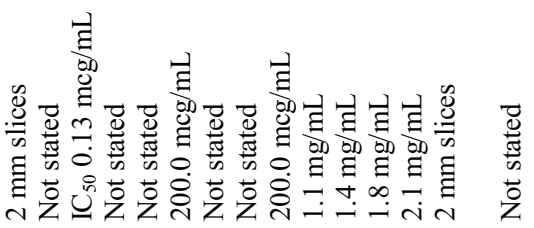

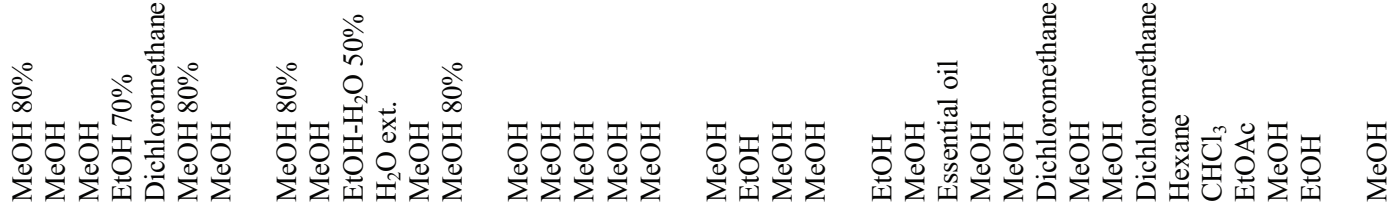

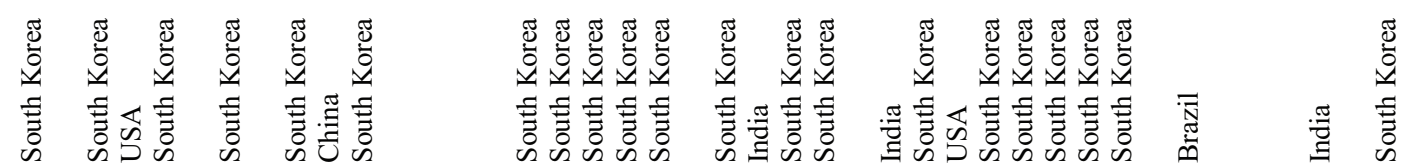

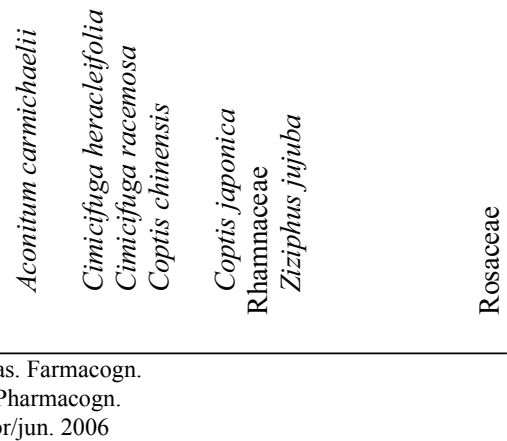




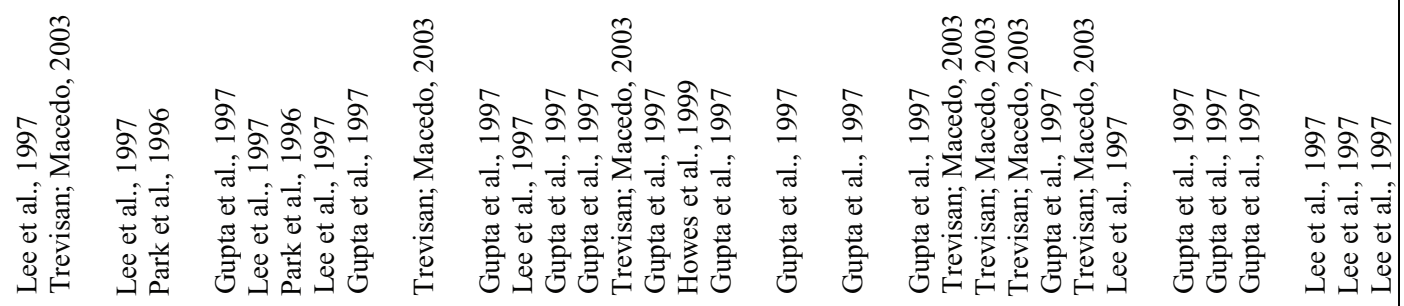

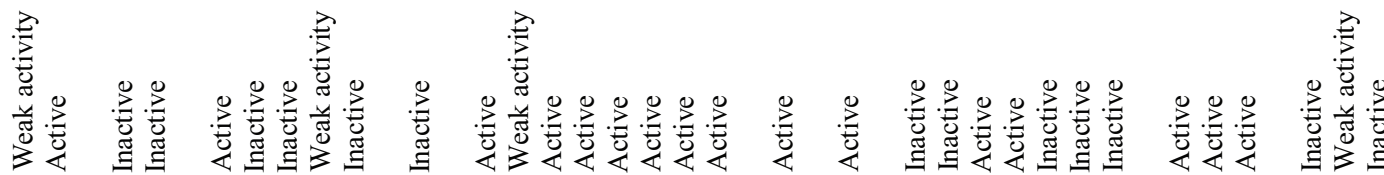

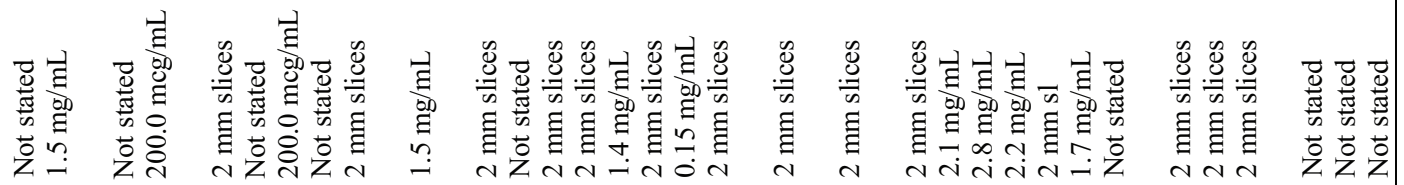

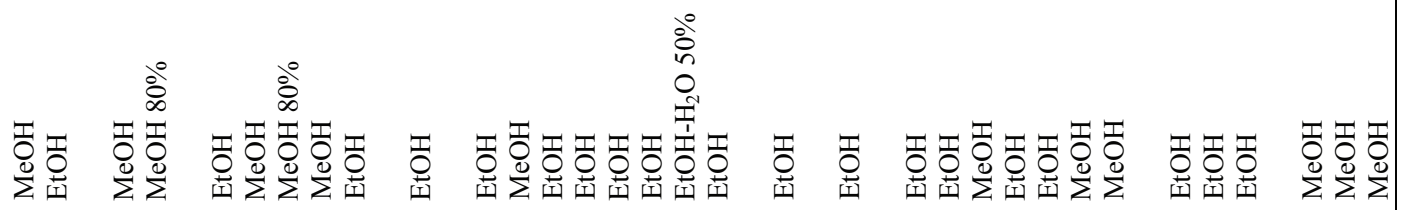

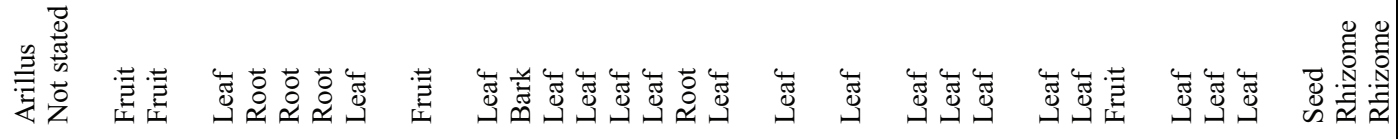

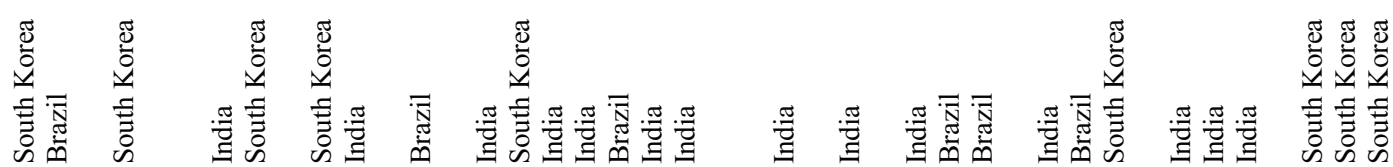

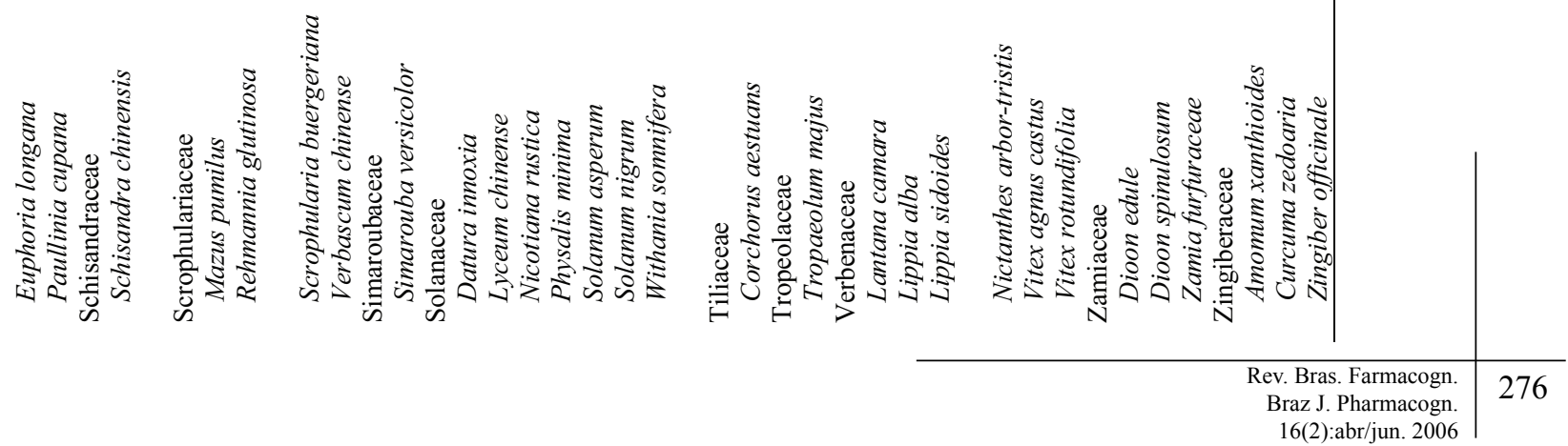




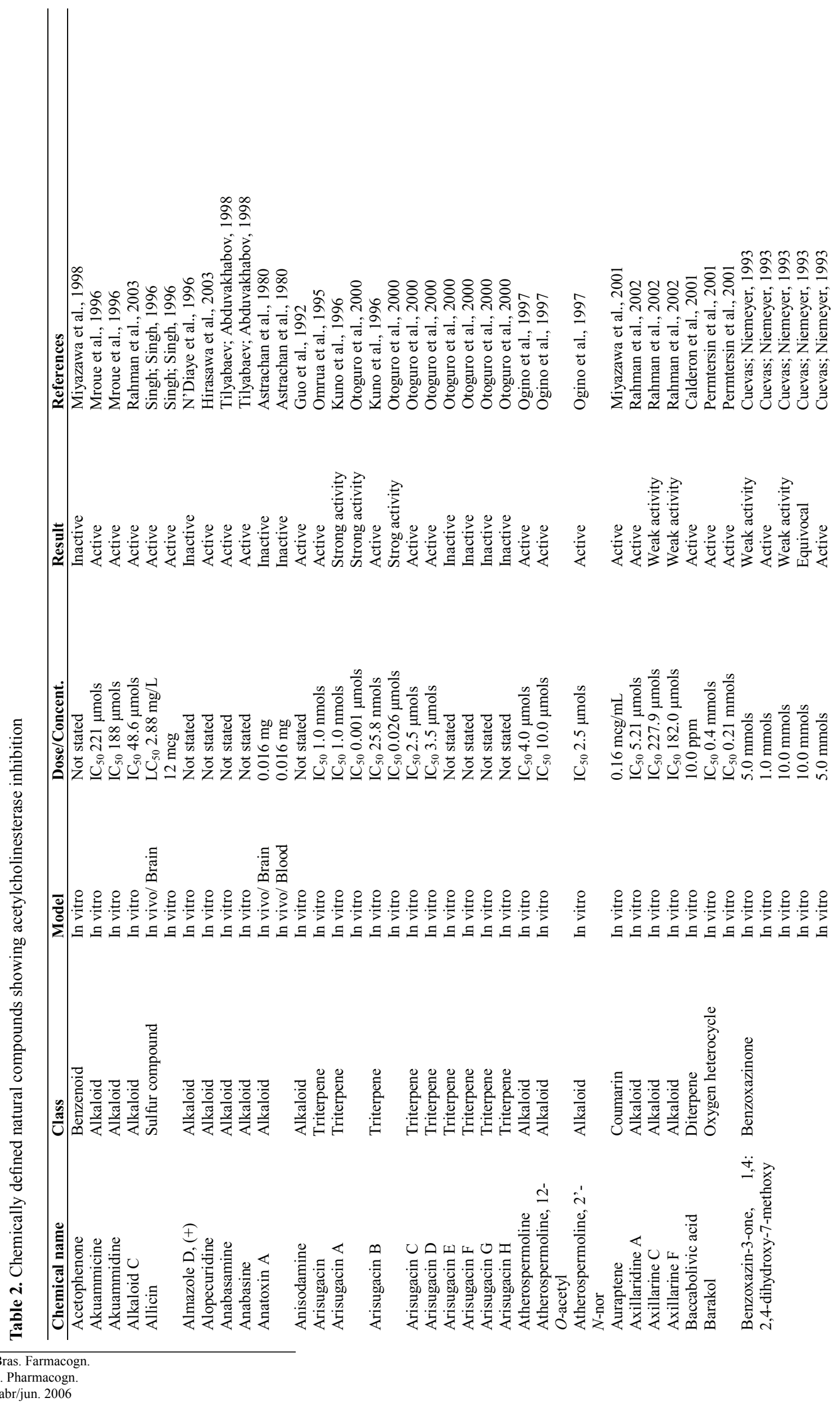




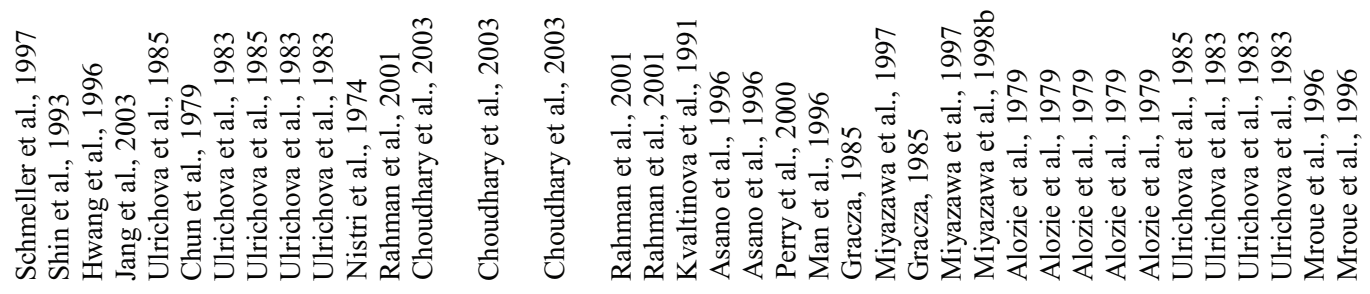

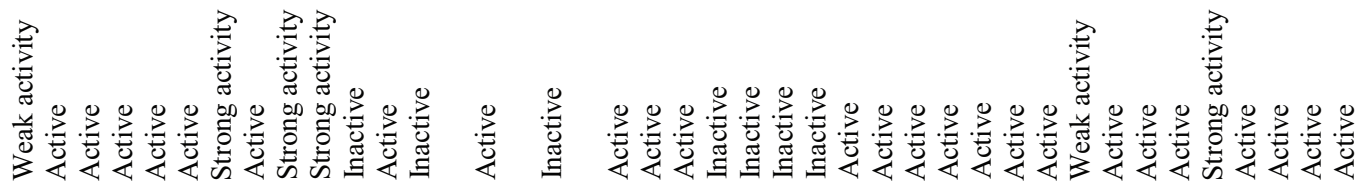

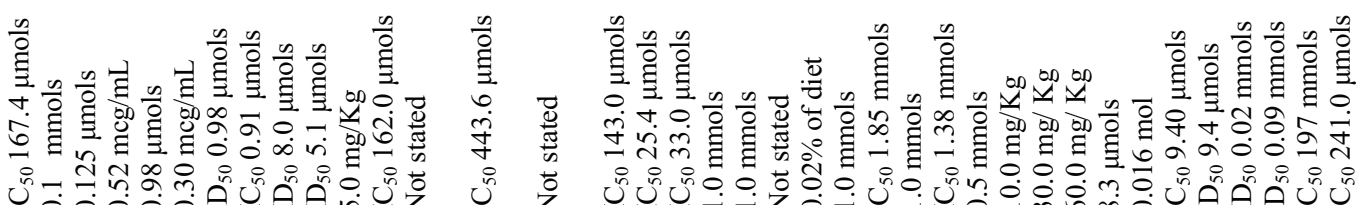

高需高

善

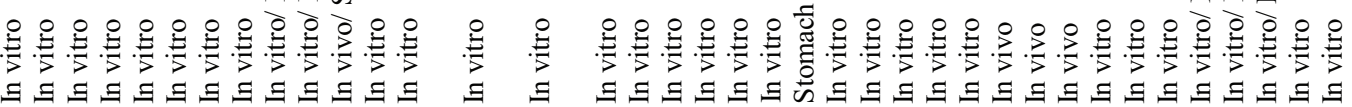

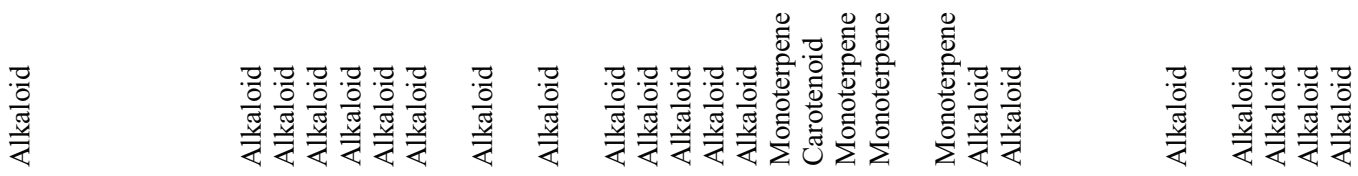

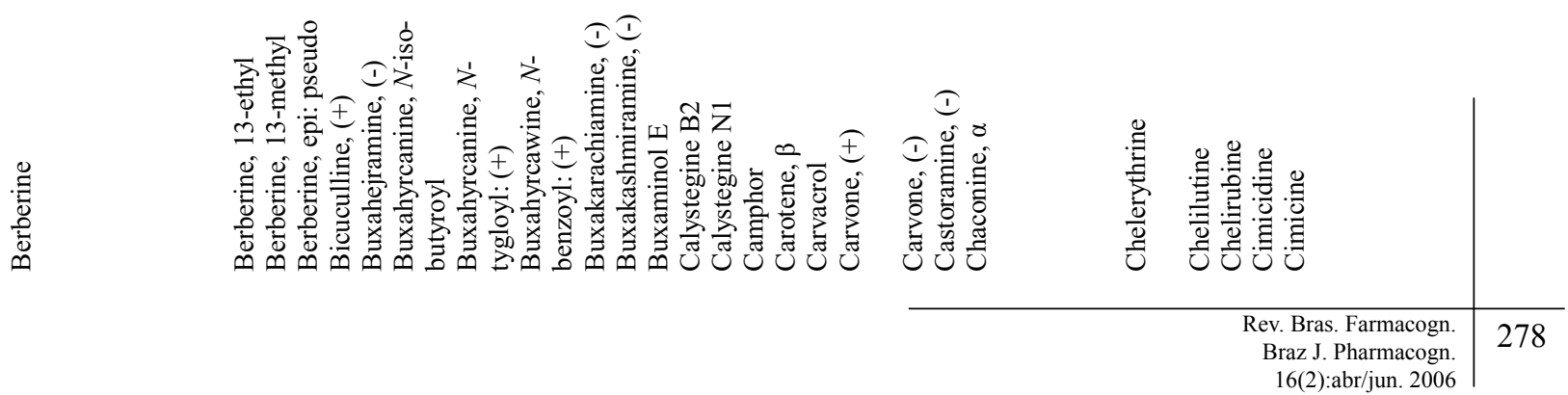



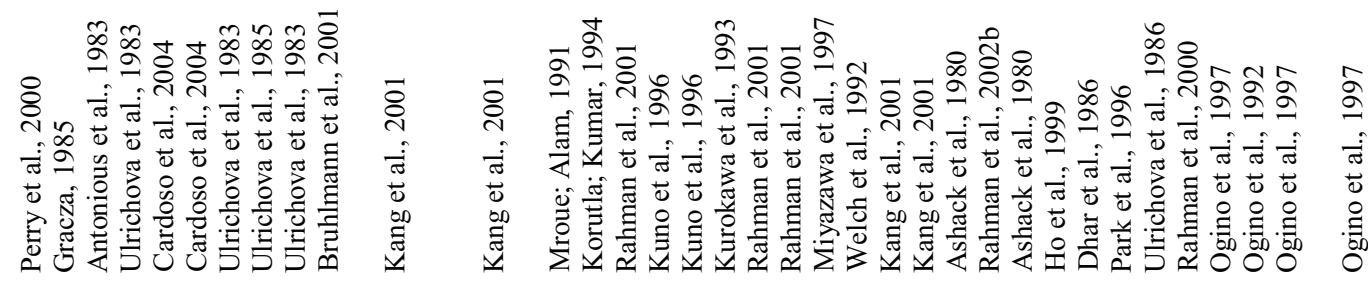

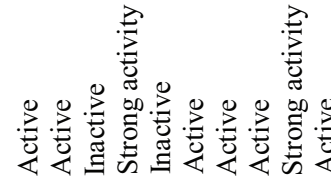

辛

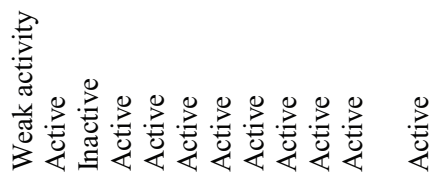

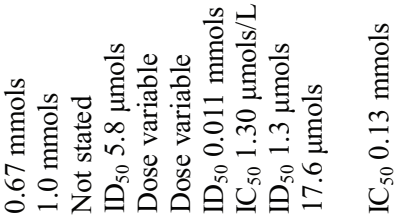

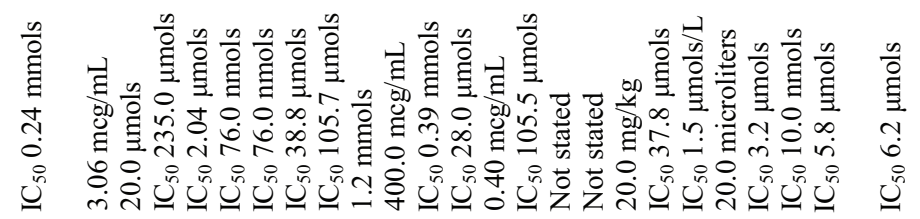

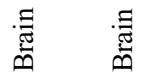

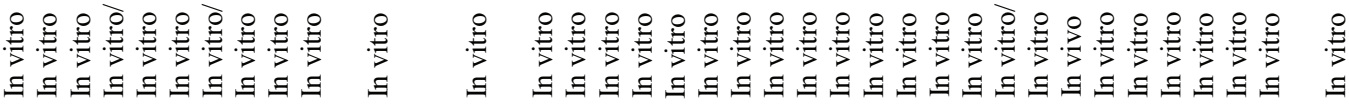

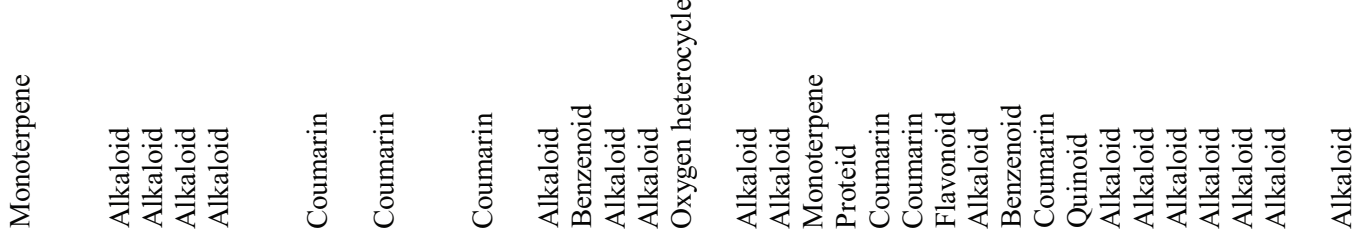

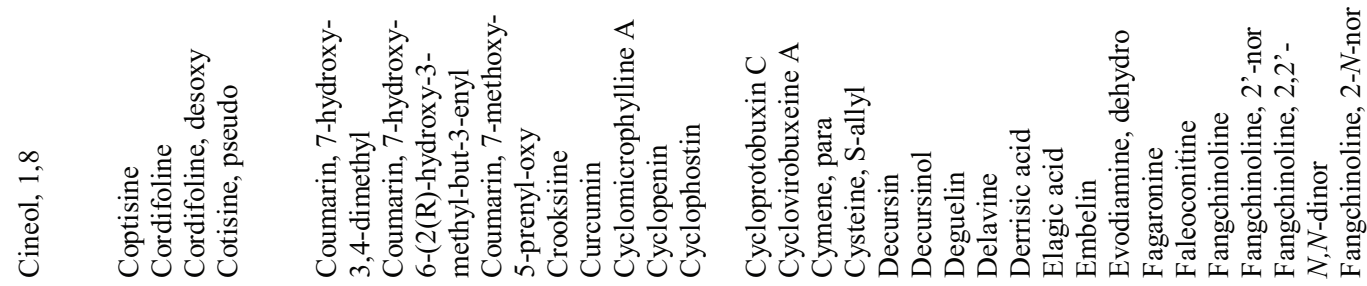




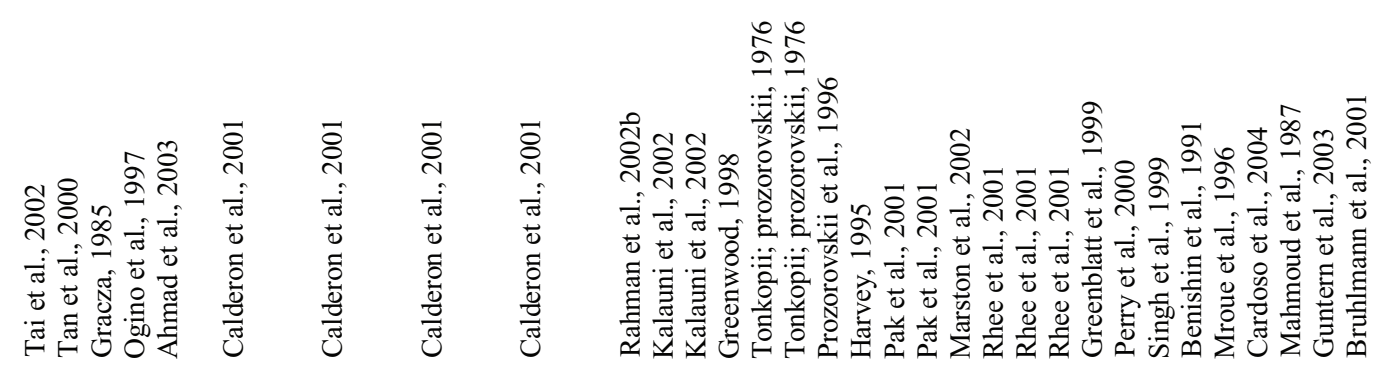

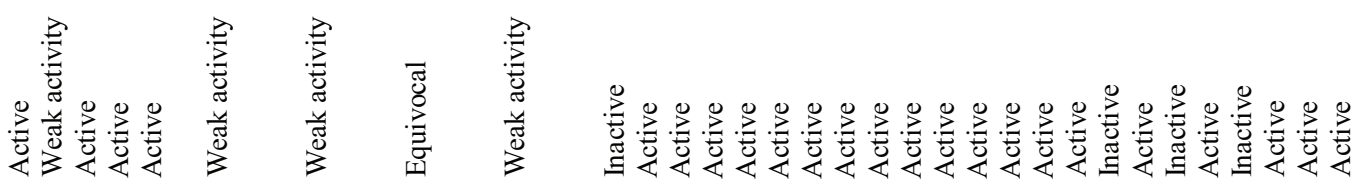

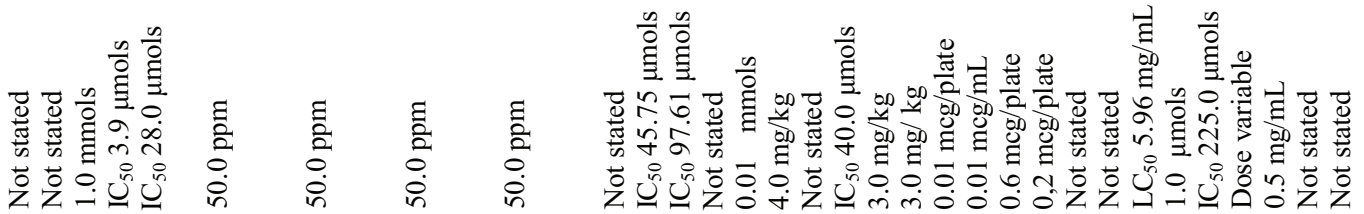

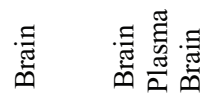

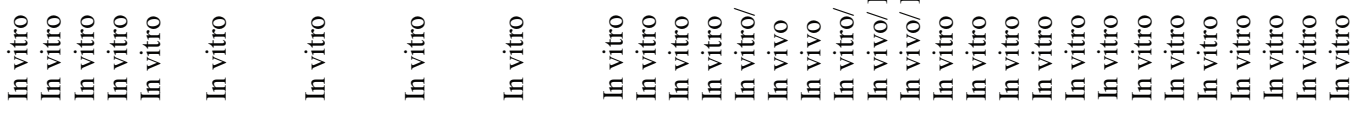

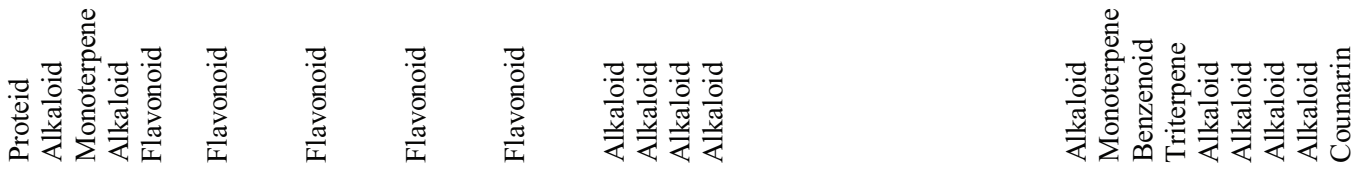
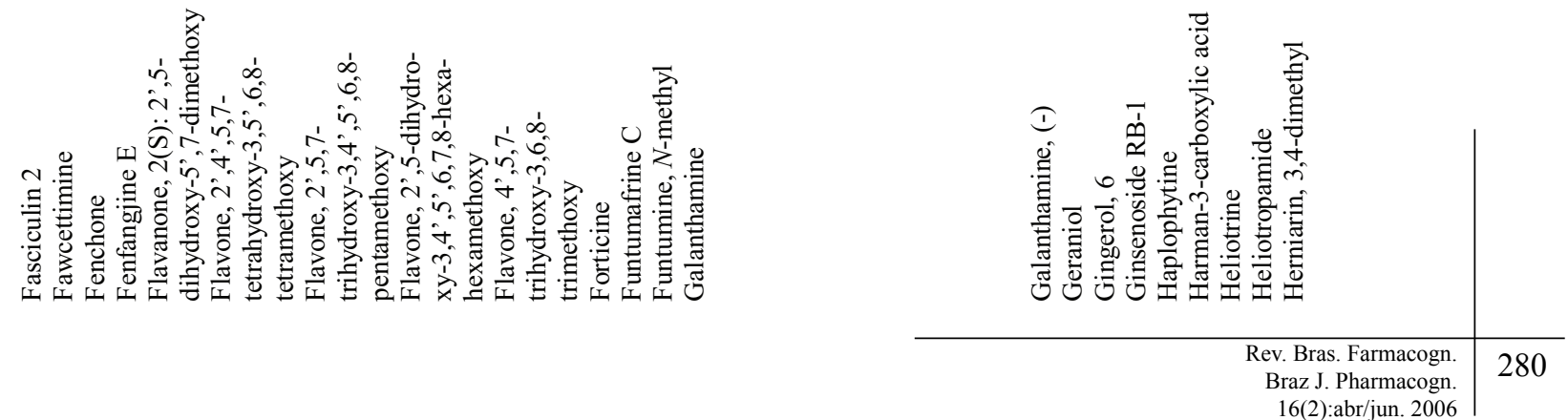


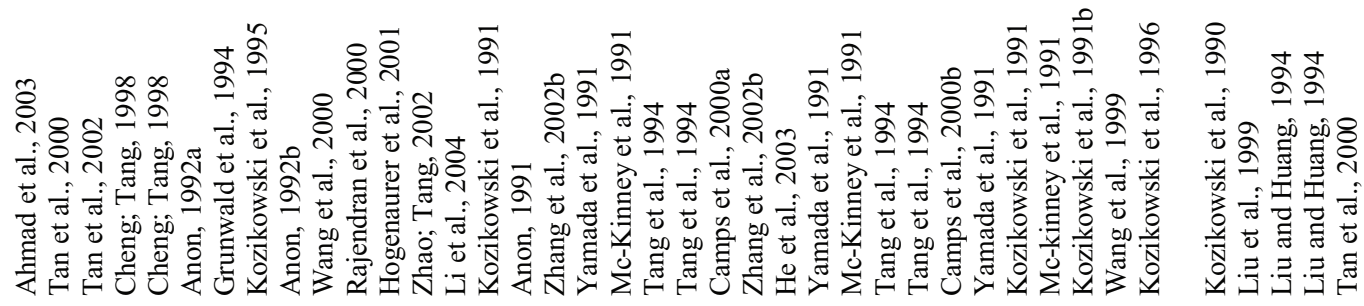

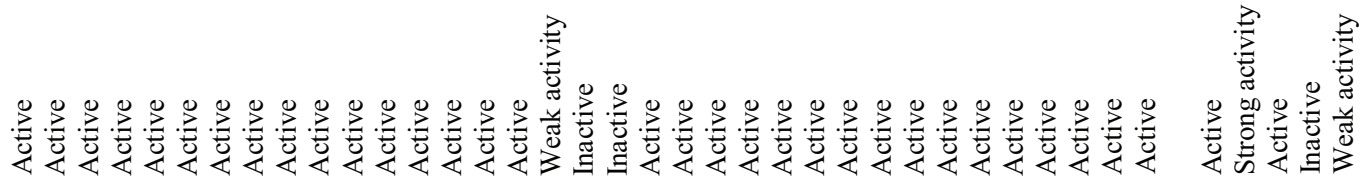

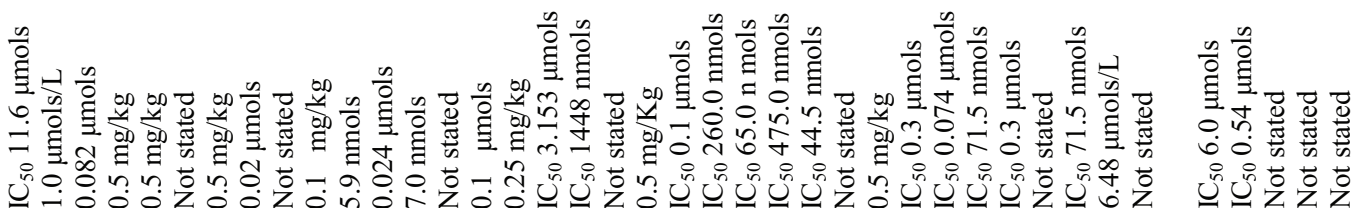

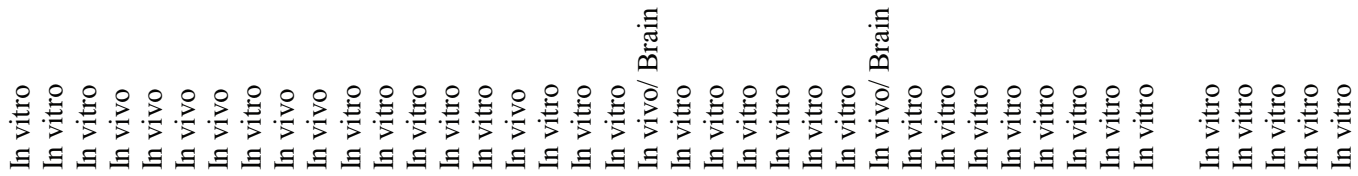

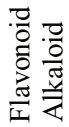

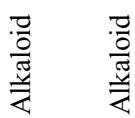

$\frac{\sqrt[7]{0}}{\frac{\sqrt{0}}{2}}$

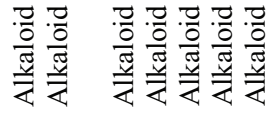

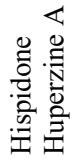

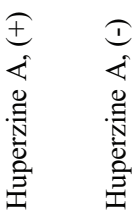

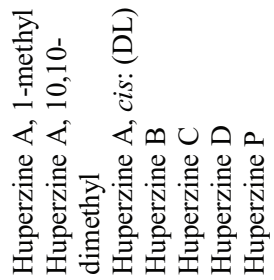




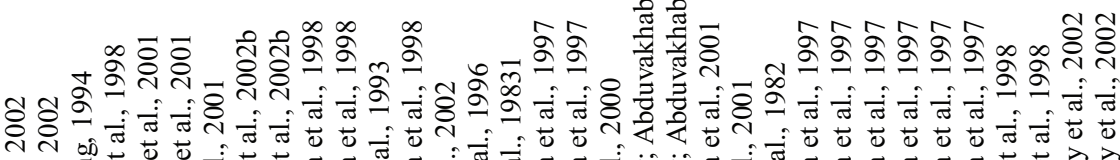

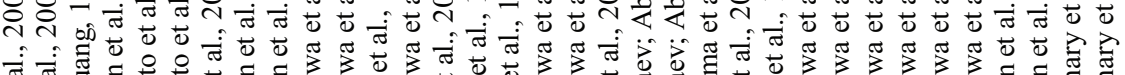

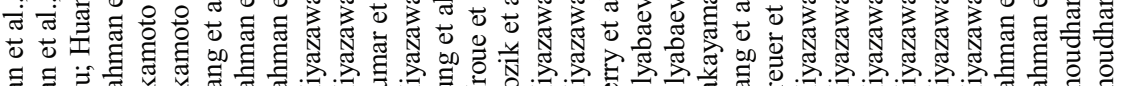

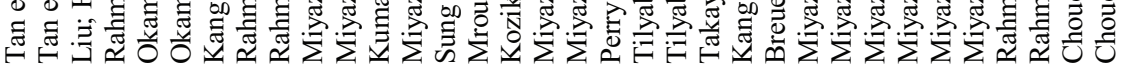

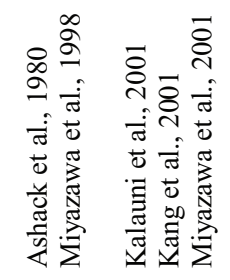

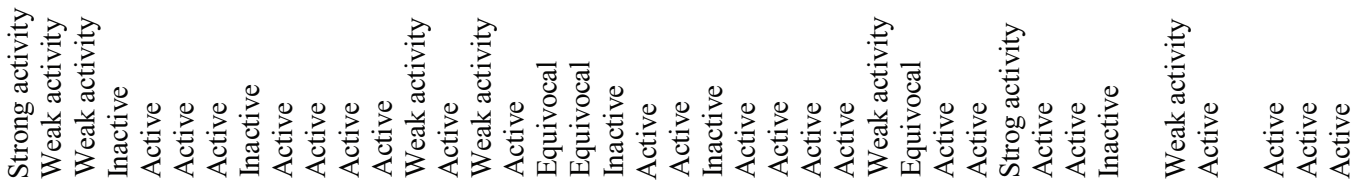

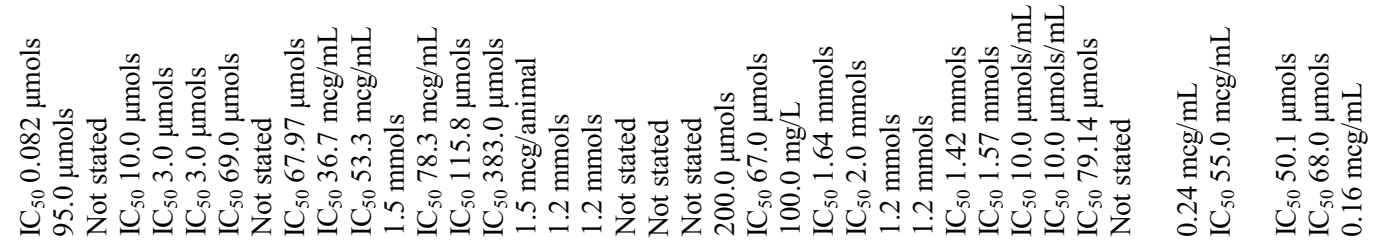

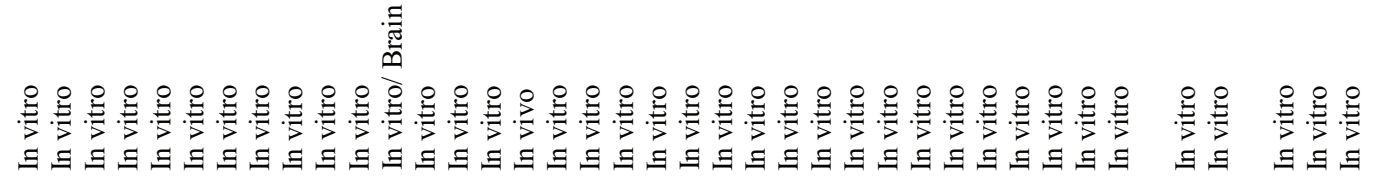

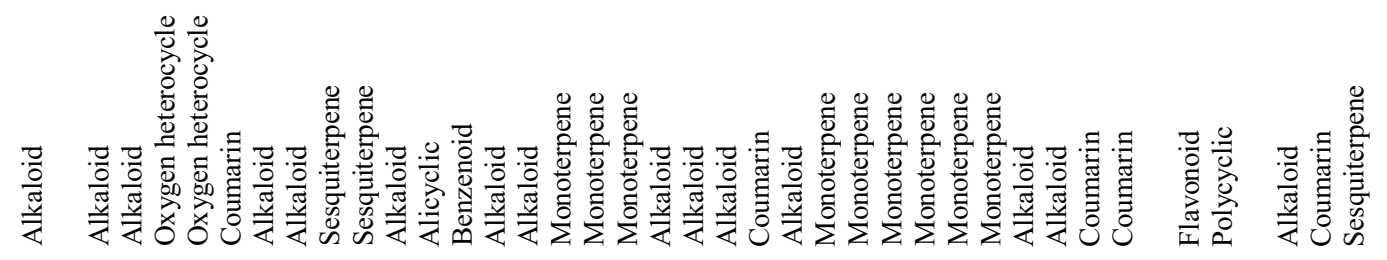

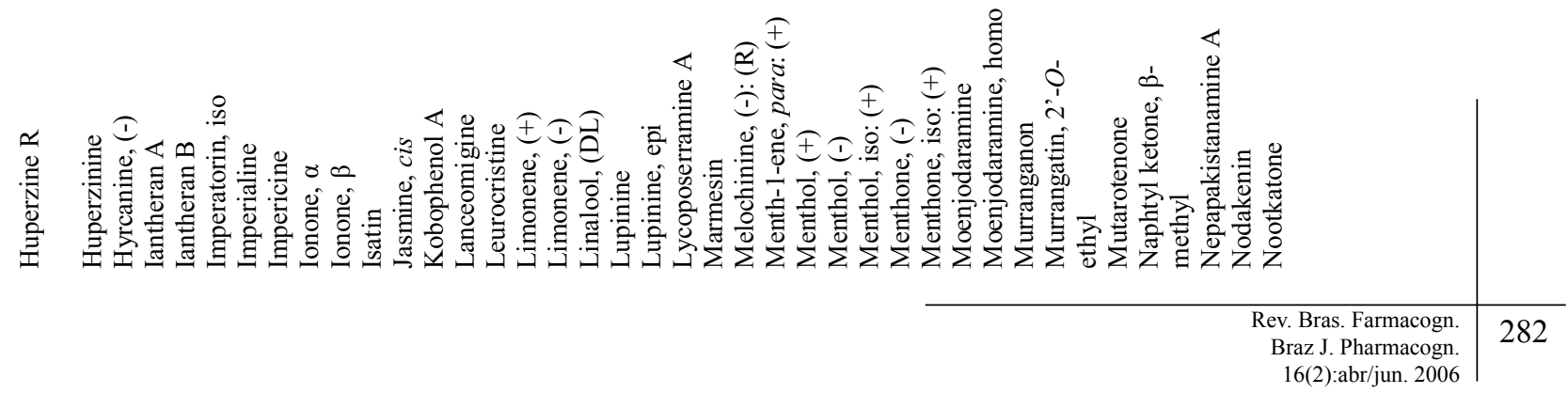




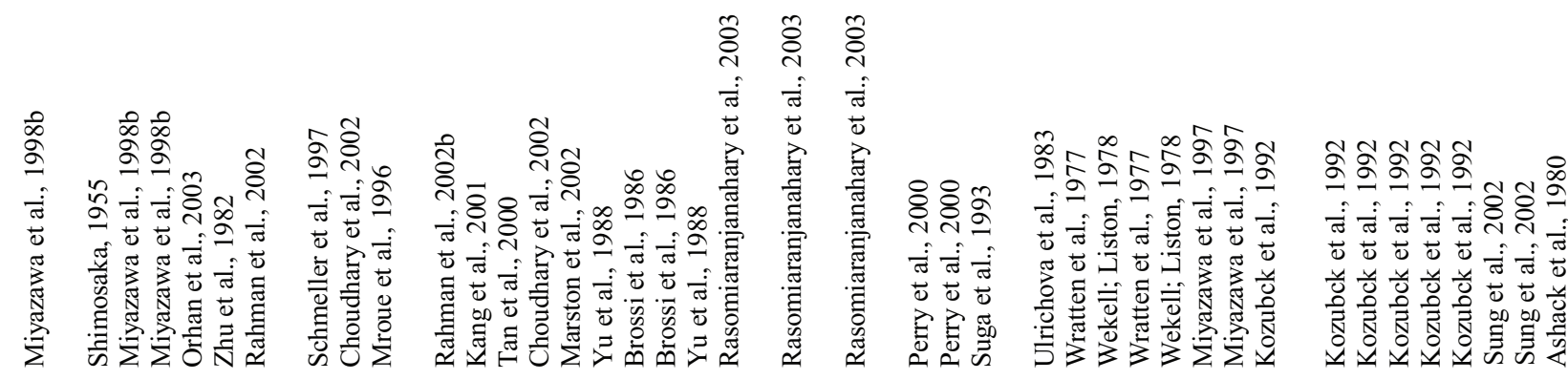

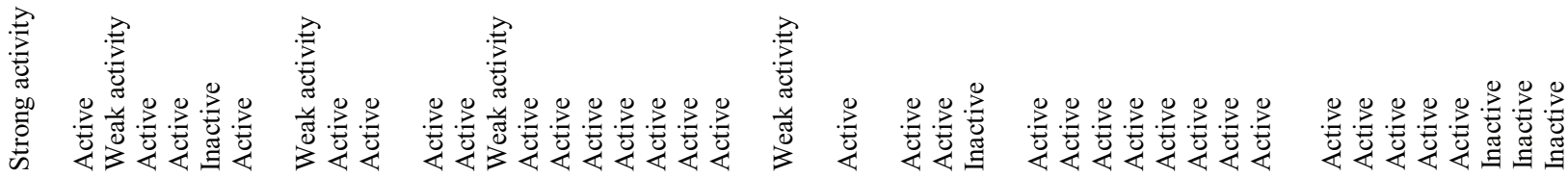

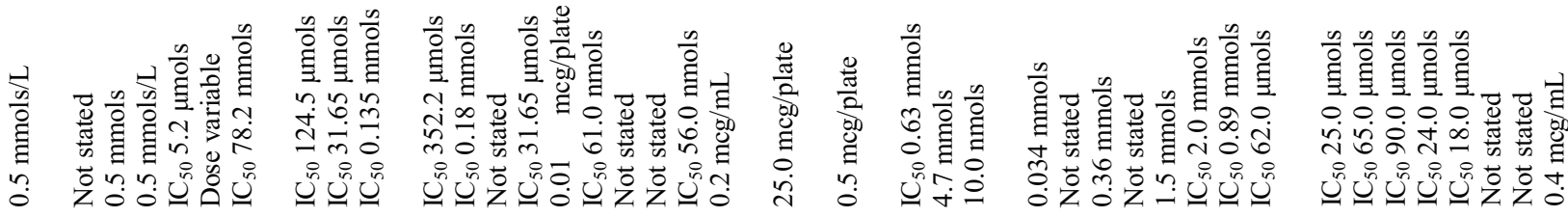

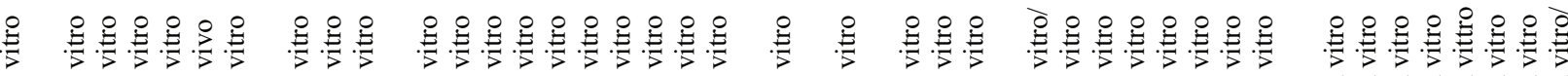

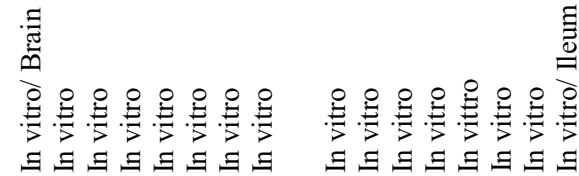

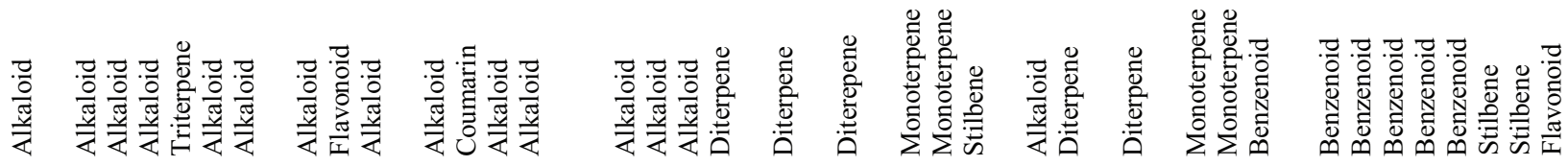

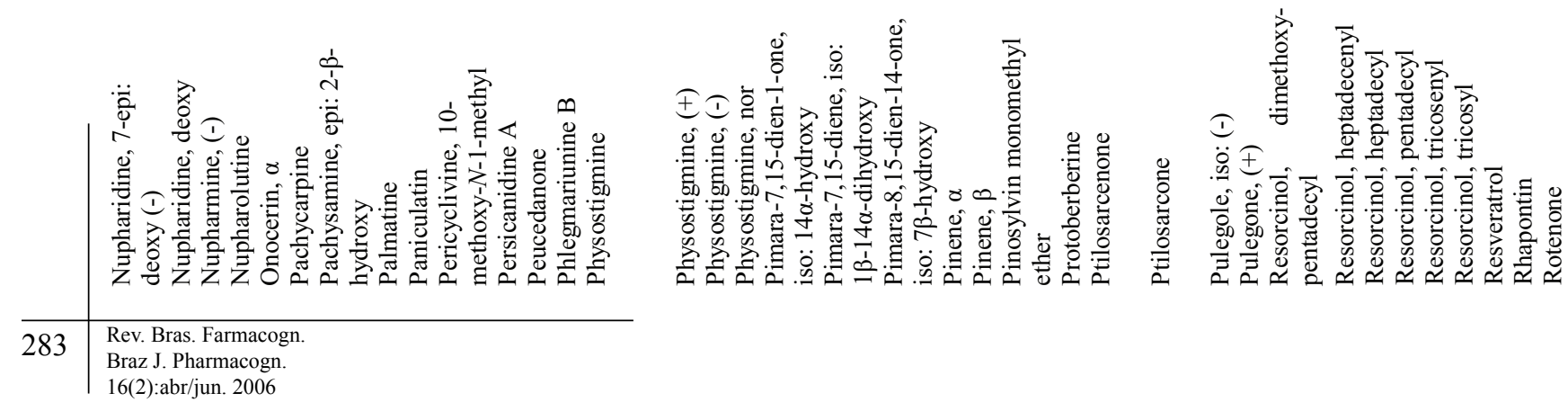




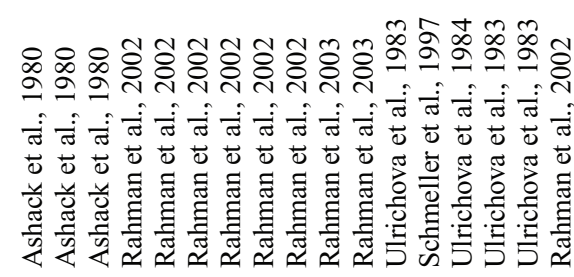
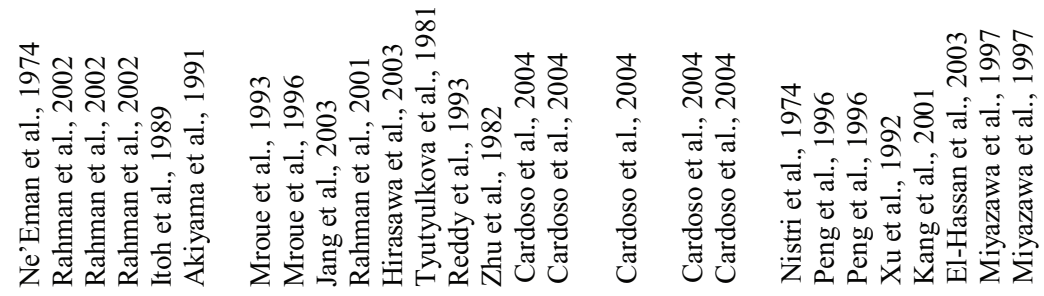

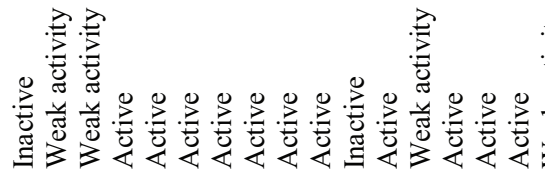

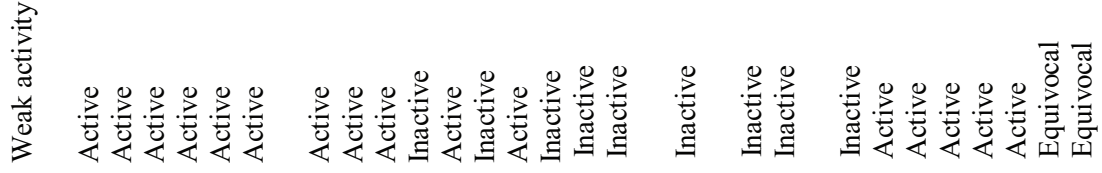

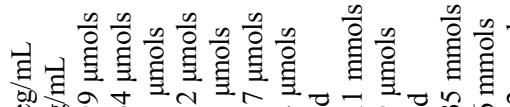

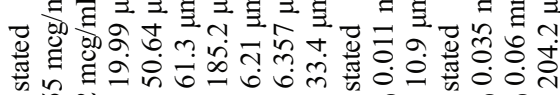

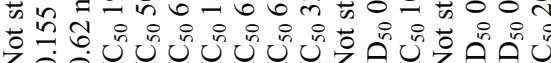

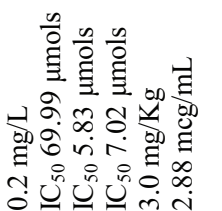

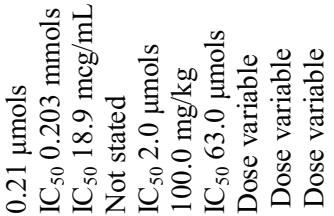

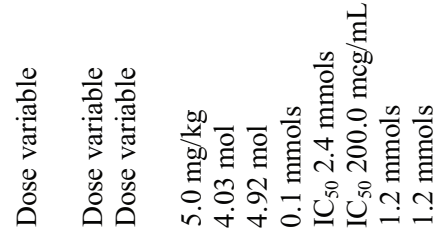

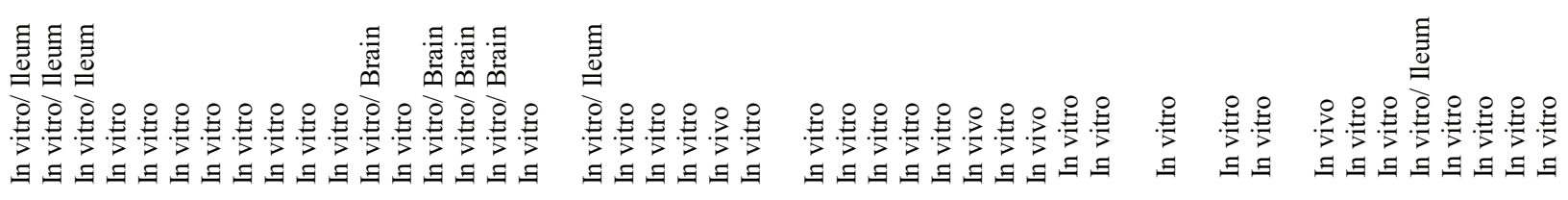

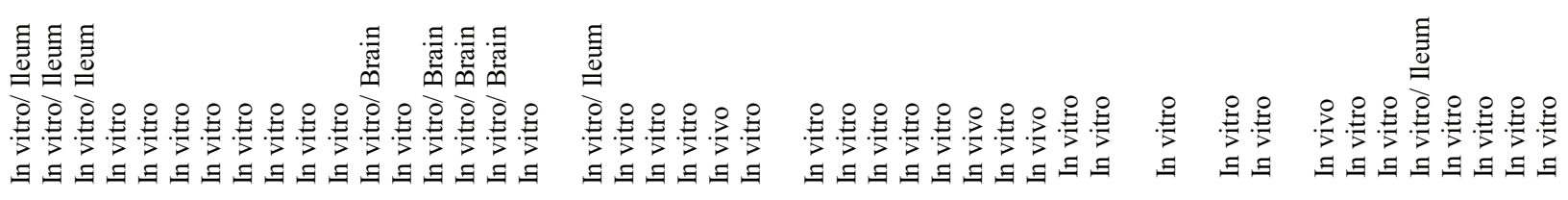

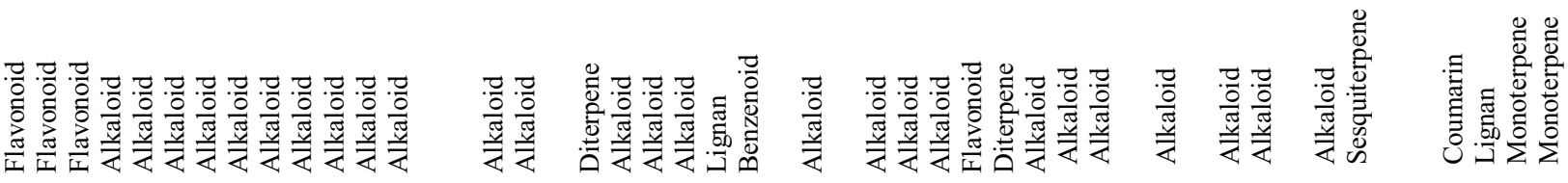

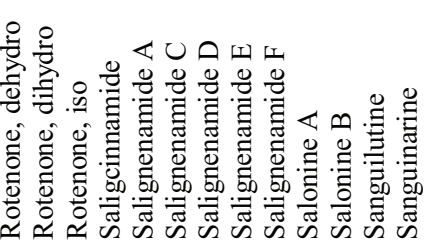

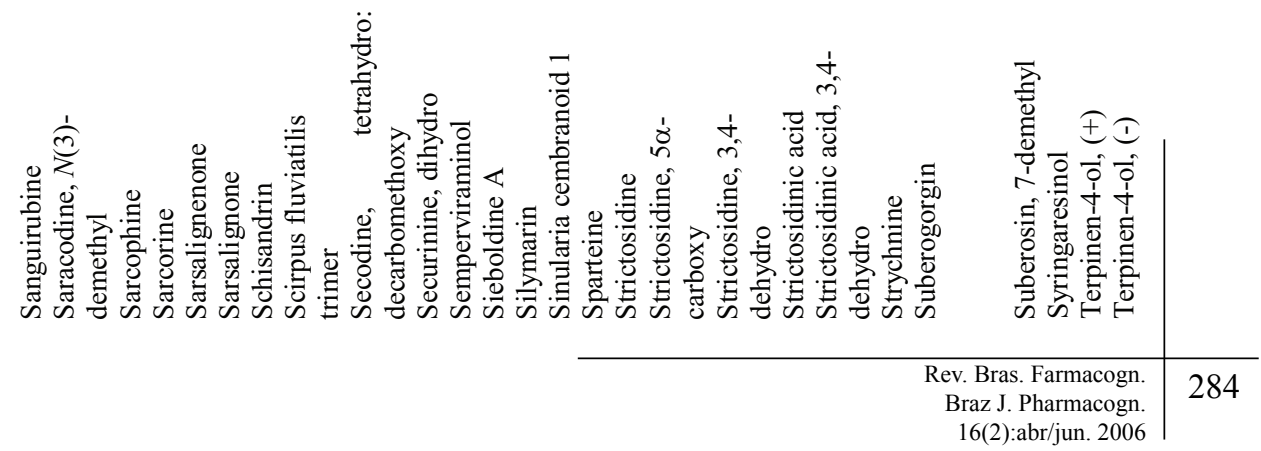



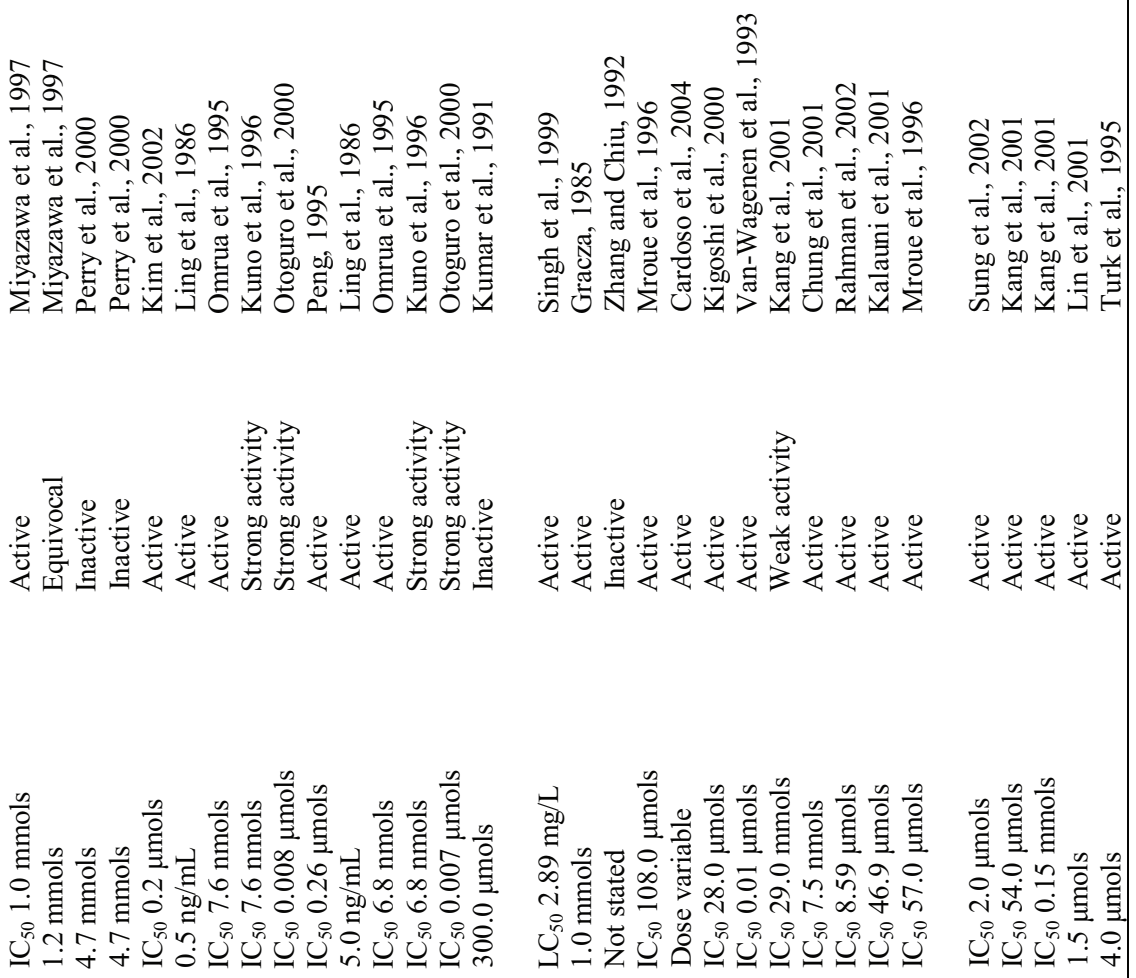

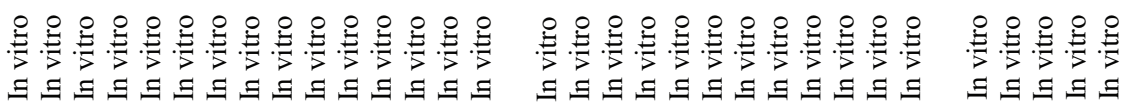
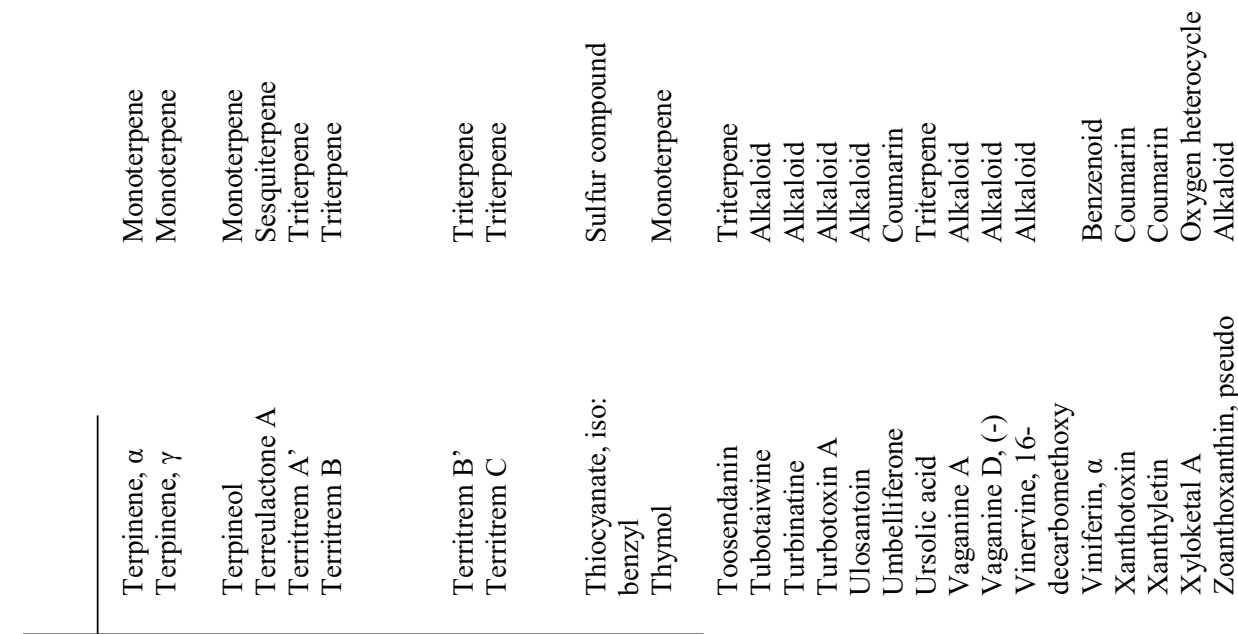